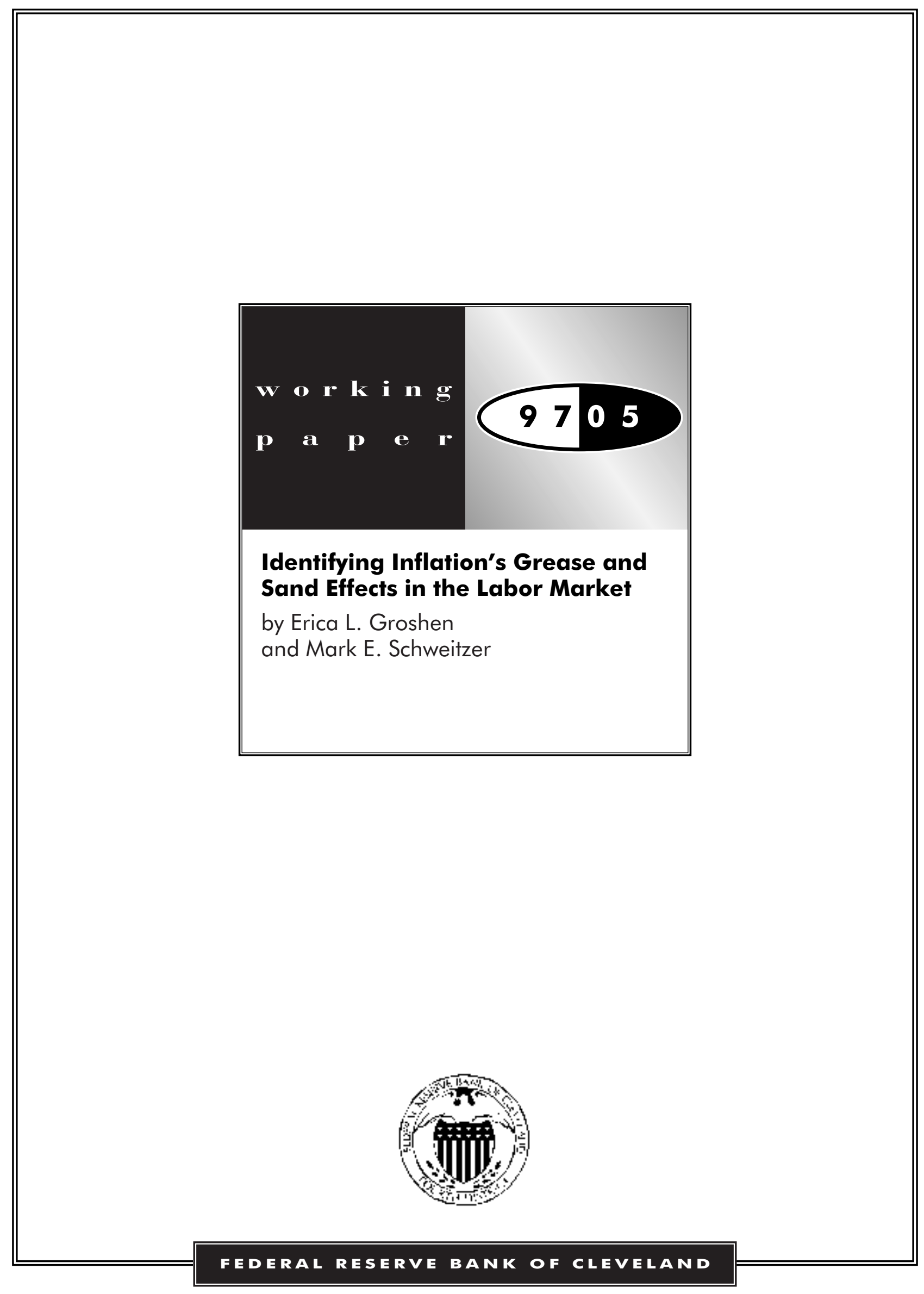


May 1997

\title{
Identifying Inflation's Grease and Sand Effects in the Labor Market
}

\author{
Erica L. Groshen \\ Federal Reserve Bank of New York \\ Mark E. Schweitzer \\ Federal Reserve Bank of Cleveland
}

Prepared for the NBER Conference on the Costs and Benefits of Achieving Price Stability, held on February 20-21, 1997 at the Federal Reserve Bank of New York.

The authors thank Karen Schiele and Christy Rollow for excellent and timely research assistance.

The views expressed in this paper are those of the authors and are not necessarily reflective of views at the Federal Reserve Banks of New York and Cleveland, or the Federal Reserve System. Any errors or omissions are the responsibility of the authors. 


\begin{abstract}
Inflation has been accused of causing distortionary price and wage fluctuations (sand) as well as lauded for facilitating adjustments to shocks when wages are rigid downwards (grease). This paper investigates whether these two effects can be distinguished from each other in a labor market by the following identification strategy: inflation-induced deviations among employers' mean wage-changes represent unintended intramarket distortions (sand), while inflation-induced, inter-occupational wage-changes reflect intended alignments with intermarket forces (grease).

Using a unique 40-year panel of wage changes made by large mid-western employers, we find a wide variety of evidence to support the identification strategy. We also find some indications that occupational wages in large firms gained flexibility in the past four years. These results strongly support other findings that grease and sand effects exist, but also suggest that they offset each other in a welfare sense and in unemployment effects. Thus, at levels up to five percent, the net impact of inflation is beneficial but statistically indistinguishable from zero. It turns detrimental after that. When positive, net benefits never exceed a tenth of gross benefits.
\end{abstract}

Erica L. Groshen

Research and Market Analysis Group Federal Reserve Bank of New York 33 Liberty Street New York, NY 10045
Mark E. Schweitzer

Research Department

Federal Reserve Bank of Cleveland P.O. Box 6387

Cleveland, $\mathrm{OH} 44101$ 


\section{Introduction}

Monetary authorities around the industrialized world achieved a major disinflation during the late 1980s and early 1990s. Now they must select implicit or explicit inflation goals for the future. On the real side of the economy, the choice boils down to weighing inflation's purported benefits as it "greases the wheels" of the labor market against the expected costs imposed by its simultaneous tendency to disrupt ("add sand to") wage and price adjustments. ${ }^{1}$ Empirical guidance for this choice is scant because of the paucity of modern experience with low inflation rates. This paper and its companion study (Groshen and Schweitzer, 1996) are intended to help fill that gap.

Grease and sand effects can both arise from nominal rigidities in wages or prices in the face of shocks. Beyond that shared characteristic, however, the effects are theoretically and empirically distinct. The grease effect arises from downward rigid wages (usually attributed to money illusion, social standards of fairness, or pervasive nominal contracts) in an economy with real economic shocks. Inflation, then, facilitates real intermarket price adjustments, reducing the extent to which the nominal rigidities bind and depress employment and output.

By contrast, the sand effect arises from errors (due to uncertainty and maintained for a contract period) or idiosyncratic nominal rigidities (due to menu costs or timing constraints) in the face of aggregate nominal shocks. Hence, inflation - when not universally recognized by market participants - raises the variance of intramarket wage or price adjustments, changing relative prices and wages, which misdirects resources and lowers output below potential.

As inflation rises, these grease and sand effects offset each other in a welfare sense. When inflation is low, their net impact may be positive. However, at higher rates, the grease effect is bounded (by the size of real shocks), so sand effects are expected to dominate.

\footnotetext{
${ }^{1}$ For further articulation of the grease and sand effects, respectively, see contrasting lectures--both titled "Inflation and Unemployment"--by James Tobin (1972) and Milton Friedman (1977).
} 
Individual empirical tests for grease and sand effects (the former in labor markets, and the latter primarily in retail markets) yield mostly affirmative results. However, except for this paper and its companion study (Groshen and Schweitzer, 1996), these studies have two crucial weaknesses that limit their usefulness for policy. First, each paper focuses on only grease or sand, omitting consideration of the offsetting effect and yielding no estimate of net impact. ${ }^{2}$ Second, the studies largely rely on out-of-sample projections to predict the impact of low inflation, because of the scarcity of recent lowinflation episodes. The latter is problematic because relationships estimated under moderate or high inflation may not carry over to low rates. In particular, inflation itself lowers incentives to relax rigid wages. Under persistent low inflation, competition should pressure employers to adopt more flexible practices (such as contingent contracts or bonus and incentive pay), which could mitigate inflation's grease or sand effects.

Our two studies are the only ones to include coverage of low-inflation years (in the 1950s, 1960s, and 1990s) and to estimate and compare simultaneous grease and sand effects. We find empirical evidence of both effects in the labor market, and that the net impact of inflation is positive but statistically indistinguishable from zero at low levels of inflation, turning negative at rates of over 5 percent.

This study has two aims: to further test the identification strategy for grease and sand used in Groshen and Schweitzer (1996), and to expand our understanding of the impact of low inflation by adding four low-inflation years (1993 through 1996) to the data. We ask whether sand effects are actually distinguishable from grease effects, and large enough (even at low-to-moderate rates of inflation) to offset estimated grease effects. We also use the most relevant evidence available (the late 1950s, early 1960s and 1992 - 1996) to focus on the labor market effects of low inflation in the US.

We proceed as follows: The next section relates the formal model of grease and sand presented in Groshen and Schweitzer (1996) to wage-setting procedures in large firms and then summarizes that paper's strategy and main findings. The third section describes the updated data set. The fourth section presents a decomposition of wage

\footnotetext{
2 Another exception, Kahn (1995), notes evidence of "menu cost" (sand) effects, but focuses on the grease effects.
} 
changes and examines the distribution of those components under high and low inflation. The fifth section re-estimates the basic statistical model from Groshen and Schweitzer (1996) on the extended sample and tests for the sensitivity of the results to the following: separating inflation from productivity, adding controls for trend and unemployment, and splitting inflation into its expected and unexpected components. The sixth evaluates net unemployment implications of our results and compares our results to two previous grease-only studies. The final section concludes.

\section{Grease, Sand and Wage-Setting Practices Under Low Inflation}

This section discusses how inflation acts on wage-setting in large US firms to produce the grease and sand effects, and reviews findings from Groshen and Schweitzer (1996), in order to set the stage for the empirical work that follows.

\section{a. A Narrative Model of Inflation's Impact on Large Firms' Wage Adjustments}

Groshen and Schweitzer (1996) develops a simple formal model to demonstrate that inflation could simultaneously raise both intentional and distortionary wage changes. The model also motivates empirical tests of the effects. Here, we show how the model incorporates institutional wage-setting practices that salary surveys (such as the one analyzed here) were designed to inform. This description is based on discussions with personnel executives, compensation textbook descriptions of the process, and compensation managers' responses to surveys conducted by Levine (1993) and others. ${ }^{3}$

The main elements of the Groshen and Schweitzer (1996) model are simply listed: The starting point is a standard efficiency wage model (where firms optimize both over labor and wages), in the context of inflation and distinct occupational labor markets. Grease and sand effects result from two added complications: (1) Inflation causes firms to commit and correct errors as they set annual wage levels. (2) Nominal wages are rigid downwards, despite the presence of relative wage shocks among occupations. The net result is that if the sand effect exists, it can be detected as an inflation-induced increase in

\footnotetext{
${ }^{3}$ Examples of compensation policy references that describe and recommend these practices include Hills(1987), Milkovich and Newman (1990), and Wallace and Fay (1988).
} 
inter-employer wage-change variation. Similarly, if the grease effect exists, inflation raises inter-occupational wage-change variation.

To see how the model's elements correspond to observable features of salary administration, it is crucial to recognize that most large US firms use a two-step process to set annual wages. In the first step, senior management sets the average nominal adjustment for the work force -- using inflation forecasts, labor market salary surveys, and financial, sales, and product price projections. In the second step, the annual "pool" for raises is divided among workers. During each phase, a different layer of management aims to maintain the company's profitability by not over- or under-paying employees, to prevent both unwanted turnover and excessively high labor costs.

To guide their decisions, many employers share wage information through community, industry and occupational wage surveys. ${ }^{4}$ A Conference Board study (Freedman, 1976) found that while compensation executives considered diverse factors in their determination of wage adjustments, area salary surveys and cost-of-living measures were particularly prominent.

At the first step of the process, employers usually pursue their wage-setting goal by maintaining parity with other employers they consider comparable. The organizational behavior literature describes firms as choosing a long-term labor market "position." This stable wage differential between the firm and alternative employers yields a work force quality or effort differential consistent with the firm's overall production strategy. This wage-setting behavior closely mimics that described in the efficiency wage literature. Indeed, the efficiency wage hypothesis is most often used to link wages and job characteristics in large, bureaucratic workplaces. Furthermore, the model's prediction that alternative wage movements feed directly into the firm's wage adjustments is consistent with descriptions of firm wage-setting exercises found in textbooks for practitioners.

The Groshen and Schweitzer (1996) model represents sand with a single inflationcorrelated term. This term can reflect employers' deviations from their intended wage

\footnotetext{
${ }^{4}$ See Groshen (1996) for a description of salary surveys and their use in research.
} 
differentials because they disagree on the expected rate of local wage inflation. ${ }^{5}$ That is, firms' compensation administrators err more often in calculating the "correct" adjustments as inflation rises because their uncertainty rises simultaneously.

This assumption is consistent with the observed tendency of inflation to raise forecast and actual goods price-change dispersion (Ball and Cecchetti, 1990 and Lach and Tsiddon, 1992, respectively). Indeed, it is implausible that firms' wage-change forecasts would be more accurate than their other price-change forecasts, since there would be strong incentives and little cost to sharing such information within the firm. Furthermore, uncertainty in market wage adjustments may well exceed that of the goods markets due to the limited samples, retrospective nature, and infrequency of salary surveys. Widespread reliance on employer salary surveys (rather than direct measures of inflation--such as the Consumer Price Index), confirms compensation managers' concerns over matching competitors' actions rather than matching some simple, easily-observed level of goods inflation. ${ }^{6}$ Of course, if a region's employers agreed on some expected inflation rate that proved incorrect, this rate would effectively operate as the true rate and not distort relative wages among the individual firms.

Supplementing the effect of errors, employers may also differ in their menu costs of adjustment because of differences in their salary administration rules, fiscal year calendars, or length of union contracts. Or, some may face cash or other constraints that temporarily prevent them from adjusting fully. These variants yield idiosyncratic lags that are also captured by the inflation-correlated term in the model.

Since these lags or mistakes and corrections affect the firm's entire salary budget, the existence of the sand effect is indicated by growing dispersion among employers' wage adjustments (controlling for skill mix) as inflation rises. These unintended variations alter firms' wages relative to the market, which can reduce profitability via high labor costs, unnecessary layoffs, work force dissatisfaction, or quits. Note also that

${ }^{5}$ By contrast, if employers were to agree on some expected inflation rate that proved incorrect, this rate would effectively operate as the true rate and would not distort relative wages among the individual firms.

${ }^{6}$ This focus makes sense because of regional divergence in wage levels and relativities (and the lack of precision of local CPIs), and because goods price movements understate average nominal wage changes by the growth of labor productivity. 
any idiosyncratic errors or lags that affect the next step (when the budget is divided among occupations), would tend to cancel out across employers, so they do not raise inter-occupational wage change dispersion.

Employers could also respond to uncertain inflation by raising their wage-change frequency, allowing use of more current information. However, this is costly, particularly for bureaucratic firms, or those with union or other fixed-term contracts. Similarly, the desire to avoid inflation-induced fluctuations may encourage companies to spend extra money gathering information to improve their decisions. These avoidance strategies also misdirect resources from their most productive uses and suggest that our metric may underestimate true sand effects.

By contrast, inflation's grease effects (its purported benefits) are conferred during the second step of the wage-setting process--the decentralized step. At this stage, corporate divisions allocate their shares of the total salary budget among workers, to match market wages and reward performance.

Divisions adjust wage differences among the occupations they employ to reflect shifts in training needs, working conditions, technology, product prices, demographics, or other input prices. In a well-functioning market, these inter-occupational wage changes influence people's job-search and training decisions. However, the division's annual decision may be altered by two constraints: the financial requirement that they not overspend their budget, and a social (or bureaucratic) restriction on cutting the wages of good performers who face unfavorable labor market conditions -- even when inflation is low. The reasons posited for this "downward wage rigidity" are money illusion, personnel practices designed to promote fairness, and the importance of fixed dollar payments in workers' expenditures.

For simplicity, the Groshen and Schweitzer (1996) model imposes complete downward nominal wage rigidity in a single-step process. This assumption could be relaxed in several ways without loss of generality. For example, in some situations the lowest acceptable raise may exceed zero. The higher the floor, the larger is the grease effect. Alternatively, some portion of pay or the workforce may not be subject to 
downward rigidity. As long as the flexible component is small relative to the size of normal shocks or the workforce, the results obtained hold.

Even more generally, downward rigid rules may also constrain wage raises during periods of low inflation. When the compensation budget binds, it limits wage adjustments to those that can be balanced by restraint on another's raise. While the traditional story of rigid wages stresses the unemployment consequences, a firm might choose to limit higher-than-average desired increases rather than lay off workers, particularly in the short run.

As an illustration, suppose the firm had two workers, each earning the same amount, but real wages for one's occupation were rising by one percent per year, while the other's were falling by one percent. Suppose also that the wage bill was restricted to grow at the rate of inflation, while firm policy prevented pay cuts. Then under zero inflation, neither worker would get a raise -- if this can be done without inducing quits. Indeed, the employer might layoff the worker in the declining occupation, if there were no complementarities in production. By contrast, in a year with one percent inflation, the worker in the slow wage-growth job would get no raise, while the other would receive a two percent hike, and there would be no incentive for layoffs.

Thus, low-inflation environments reduce the variance of occupational wage adjustments in two ways. First, they eliminate some wage cuts in declining occupations. Second, they restrain increases for other workers--in order to balance the compensation budget. Such restrictions will be evident in intentional components of wages that require occasional, substantial adjustments. The obvious candidate is occupational wage adjustments. If wage rigidity simply eliminated wage changes below a cutoff, a test for truncation would adequately verify rigidity. However, the realistic complications described above or differences in firms' inflation expectations could distort that implication. For this reason, and to maintain symmetry in our analysis, we look for wage rigidity's effect on the standard deviation of occupational adjustments, because truncation always implies a reduced variance.

In social welfare terms, the grease effect predicts that higher inflation allows divisions to lower real wages for workers facing unfavorable market conditions. That is 
inflation avoids costly alternatives such as layoffs, lowering other workers' raises (risking quits), maintaining prices above competitors paying the market wage (risking market share), and/or accepting lower profits. Then wage signals travel more rapidly throughout the economy, reducing layoffs and providing accurate incentives to workers choosing training and career paths.

A final realistic feature of our model is that it recognizes that general increases in labor productivity can substitute for inflation in both the grease and sand stories. Since broad-based productivity growth shifts out market demand for labor, firms must match other employers' productivity-based adjustments -- along with inflation -- in their average nominal wage adjustments. In light of this, we measure external wage change as the change in output prices plus the general increase in labor productivity. Ceteris paribus, this sum approximates the average nominal wage growth in the economy.

Thus, the main features of the formal model accord well with large firms' actual wage-setting practices. This supports confidence in the identification strategy generated by the model -- that inflation's negative effects can be distinguished from its positive effects because they affect different components of wage changes. On the negative side, inflation adds unintended variation to firm-wide salary adjustment budgets (sand). On the positive side, it frees divisions from downward nominal wage rigidity -- allowing firms to adjust wages more rapidly to reflect market conditions for particular occupations (grease). In the following section, we summarize the measures of these effects obtained in Groshen and Schweitzer (1996).

\section{b. Summary of Previous Results}

Groshen and Schweitzer (1996) distinguishes inflation's positive labor market effects from its negative ones in the wage changes observed in a unique, long-lived panel of occupations and employers from the Federal Reserve Bank of Cleveland Community Salary Survey (CSS).

The analysis begins by characterizing wage changes in the CSS and extracting common occupational and employer components in each city and year. As confirmation of the consistency of the model with observables, we find that: 1) As predicted, annual 
mean wage adjustments are highly correlated with external measures of inflation and productivity growth. 2) An ANOVA of annual wage changes verifies that employer and occupation components both play statistically strong, independent roles. 3) Over time, the dispersion of employer and occupation adjustments display a correlation coefficient of only 0.48 ; these two components of wage change dispersion often move independently.

Next, we regress the standard deviation of the estimated occupation and employer components on external nominal wage growth (inflation plus productivity growth). Since productivity growth, unlike inflation, has other unambiguous benefits and is not a direct monetary policy target, we focus on implications for inflation policy.

The empirical results suggest that potentially beneficial grease (as measured by the standard deviation of occupational wage adjustments) shows a diminishing relationship with nominal wage growth. These potential benefits taper off after inflation rates of about 3-4 percent (assuming labor productivity growth of $1 \frac{1}{2}$ percent, the average rate over the period observed). By contrast, disruptive sand from additional inflation (as measured by the standard deviation of employer wage adjustments) rises about twice as quickly as occupational variation with respect to inflation and shows less evidence of a turndown at inflation levels over 7 percent. The robustness of these results is confirmed by nonparametric, filtered, and panel versions of the tests.

We then combine the two gross results to consider the net (i.e., grease minus sand) impact of inflation. This is possible if the two effects are measured in the same units on the same data, are equally well identified, and subject firms to symmetric losses. Assuming productivity growth of $1 \frac{1}{2}$ percent, net benefits peak at $2 \frac{1}{2}$ percent inflation. Maximum net benefits amount to about a tenth of the gross benefits, and are not statistically different from zero. At inflation levels above 5 percent, the disruptive effects of inflation on the labor market overwhelm the positive impacts, and net benefits turn negative. Thus, in contrast to many grease-only studies, we conclude that the labor market provides little guidance on the preferred inflation goal at the low end of the range. 


\section{The Community Salary Survey}

This study uses an updated version of the annual private salary survey data described in Groshen and Schweitzer (1996). The Federal Reserve Bank of Cleveland has conducted the CSS in Cleveland, Cincinnati, and Pittsburgh since 1927 to assist its annual salary budget process. The analysis data set reports wages for detailed occupations, by employer from 1956 through 1996.

The data set has three major selling points for this study. First, the wages recorded here are less prone to random reporting error than household data because they derive from administrative records. Second, the data are longer-lived than any source previously investigated. Third, because employer data records wages in the way most meaningful to firms, it is preferable to household or aggregate data for studying impacts on firms' wage-setting. This perspective appropriately reflects the strategies used by firms to adjust wage bills (e.g., promotions, reassignments or reorganization), but not the potentially confounding means used by workers individually to adjust their earnings (e.g., taking second jobs or changing hours).

Table 1 describes the dimensions of the CSS wage-change data set. From wage levels, we compute 75,765 annual wage changes for occupation-employer ("job") cells observed in adjacent years. ${ }^{7}$ Each observation gives the change in the log of the mean or median salary for all individuals employed in an occupation-employer cell. ${ }^{8}$ Cash bonuses are included as part of the salary, although fringe benefits are not.

Participants in each city are chosen to be representative of large employers in the area. Until 1995, the number of companies participating trended up from 66 to over 80 per year (see table 2). On average, they stay in the sample for almost 13 years each.

${ }^{7}$ Job-cell-year observations where the calculated change in log wages exceeds 0.50 in absolute value are deleted from the sample on the assumption that most of these arise from reporting or recording errors. Over 1,000 observations are imputed from cases where job-cells are observed two years apart. The imputed one-year changes are simply half of the two-year differences. Many of the results reported here were also run without the imputed observations. Their inclusion does not affect the results.

${ }^{8}$ Only means were recorded before 1974 . Since medians should be more robust to outliers, our results use means through 1974 and medians for the years thereafter. Comparison of the coefficients estimated separately for means and medians for some years where both were available (1974 and 19811990) suggests that they are highly correlated (correlation coefficients of .97 to .99). However, coefficients 
Since each participant judges which establishments to include in the survey, depending on its internal organization, we use "employer," a purposely vague term, to mean the employing firm, establishment, division, or collection of local establishments for which the participating entity chooses to report wages. ${ }^{9}$ The industries included vary widely, although the emphasis is on obtaining employers with many employees in the occupations surveyed. ${ }^{10}$

The occupations surveyed (43 to 100 each year) are exclusively nonproduction jobs that are found in most industries, with relatively high inter-firm mobility, and welldeveloped markets. ${ }^{11}$ Many occupations are divided into grade levels, reflecting responsibility and experience. In the analysis, to avoid unnecessary restrictions, we consider each occupational grade in each city to be a separate occupation. Thus, the total number of "occupations" in table 2 exceeds the number surveyed. For example, 83 occupational grades were surveyed in 1996, yielding 240 occupations across the three cities. On average, each employer reports wages for about 27 occupations.

Although the CSS is conducted annually, the month surveyed has changed several times. Throughout the paper, results for any year refer to the time between the preceding survey and the one conducted in that year -- usually a 12-month span, but occasionally not. All data merged in have been adjusted to the extent possible to reflect time spans consistent with those in the CSS.

We also incorporate standard measures of inflation and national output per hour in our analysis (see table 3). As a measure of general inflation experienced in the country, we use percentage changes in the monthly averages of the Consumer Price Index for all

estimated with medians show more variation than those estimated on means and are more highly correlated over time, consistent with medians being a more robust measurement of central tendency.

${ }^{9}$ Some include workers in all branches in the metropolitan area; others report wages for only the office surveyed. Since a participant's choice of the entities to include presumably reflects those for which wage policies are actually administered jointly, the ambiguity here is not particularly troublesome.

10 The employers surveyed include government agencies, banks, manufacturers, wholesalers, retailers, utilities, universities, hospitals, and insurance firms.

11 They include office (e.g., secretaries and clerks), maintenance (e.g., mechanics and painters), technical (e.g., computer operators and analysts), supervisory (e.g., payroll and guard supervisors), and professional (e.g., accountants, attorneys, and economists) occupations. Job descriptions for each are at least two paragraphs long. 
Urban Workers (CPI-U). Our labor productivity measure is the Nonfarm Business Sector Output per Hour Worked (pre-chain-weights).

Mean log wage changes among the three cities are highly correlated and closely track national wage trends. Figure 1 shows the strong correspondence between the CSS three-city mean log wage change and our simple measure of nominal wage change (labeled $\mathrm{CPI}+$ ) -- which equals the sum of inflation (CPI-U) and aggregate labor productivity movements. The new observations (1993-1996) are all years in which the mean wage change in these three cities did not keep pace with CPI+. However, Groshen and Schweitzer (1996) shows that correlations between mean CSS wage adjustments and the CPI-U and $C P I+(0.84$ and 0.74 , respectively $)$ are quite high. The wages in the CSS largely adhere to national trends, and thus may enlighten us about the behavior of wages in the nation as a whole.

\section{Wage Adjustment Components}

\section{a. ANOVA of CSS Wage Changes}

Table 4 presents an analysis of variance (ANOVA) of wage adjustments in the updated CSS sample to verify the existence of distinguishable employer and occupation components. The following fixed-effects regression model is used to decompose log wage changes $\left(w_{f j}\right)$ :

$$
w_{f j}=\alpha+\beta D_{f}+\gamma D_{j}+\mu_{f j} \text {, for each locality and year, }
$$

where $\beta$ and $\gamma$ are coefficient vectors for matrices of dummy variables $\left(D_{f}\right.$ and $\left.D_{j}\right)$ referring to the cell's firm and occupation, respectively. The $\beta$ vector measures deviations from the mean wage change across the firm's complement of occupations; i.e., the general pricing deviation developed above (sand). The $\gamma$ vector represents average occupational wage adjustments made in the market.

The results are little changed by the addition of the new data. The first two columns list sources of variation and their associated degrees of freedom. Control for mean annual changes in three cities absorbs 112 degrees of freedom. To allow 
occupational wage patterns to diverge in the cities, occupation and city are interacted, accounting for 6,186 degrees of freedom. Employers' mean annual wage movements absorb another 3,001 degrees of freedom.

The third column lists each source's marginal contribution to the model sum of squares (over the contributions of the sources listed above it on the table). We choose this method of presentation -- similar to a stepwise regression -- because of its parsimony when the data are unbalanced (i.e., the occupations in each firm vary). Since the joint effects in wage-change variation between occupation and employer are minuscule, the order of presentation is unimportant.

All together, the model accounts for 27.4 percent of the variation in annual wage adjustments. The residual variation is presumably due to compositional changes, individual merit raises, and perhaps, commingled grease and sand effects. The fifth column of the table shows that slightly more than one-fifth of the equation's explanatory power stems from changes common to all job-cells in each year. Intercity differences account for little variation. Occupation-wide changes, on the other hand, constitute more than one-quarter of observed variation. By far the strongest effect is employer-wide changes, which account for close to half of the explained variation and 12.4 percent of total variation. F-statistics for these five sources of variation are all significant at the 1 percent level.

This decomposition suggests that the institutional model described above fits the data: occupation-wide and employer-wide variations in wage changes are large and statistically distinguishable from each other. In particular, the firm-wide wage movements are interesting because employer wage differentials are quite stable over long periods of time (Groshen, 1989). Thus, variation here suggests errors and corrections.

\section{b. Inflation's Impact on the Distribution of Wage Change Components}

Since the grease hypothesis is based on downward (one-sided) wage rigidity, while the sand hypothesis posits symmetrical rigidities, inflation may affect the distribution (as well as the variance) of occupation and employer wage components differently. In particular, there is no reason to think that the distribution of employer 
deviations under low inflation would not be symmetric, simply showing thinner tails than the distribution of changes under high inflation. By contrast, downward wage rigidity under low inflation implies left-hand truncation of occupational wage changes, which may vary among firms. This effect suggests that low-inflation environments will skew the distribution to the right, with little impact on the right-hand tail -- to the extent that the lack of cuts is not balanced by corresponding restraint in raises.

Figures $2 \mathrm{~A}$ and $2 \mathrm{~B}$ plot the distribution of employer and occupation wage adjustments during years of high (over 5 percent) and low (under 3 percent) inflation. Consistent with our previous results, in both panels, higher inflation is associated with higher variation. Indeed, Kolomogorov-Smirnov tests resoundingly reject equality between the high- and low-inflation distributions. Second, we note that the two sets of distributions do not look the same -- providing more evidence of a difference between the two components.

Third and most important, the density plot for employers (top panel) shows thinning in both tails as the level of inflation falls. By contrast, the density plot for occupations (lower panel) shows a marked, asymmetrical loss of small negative adjustments under low inflation -- consistent with truncation. The tails are virtually unaffected. The fact that inflation affects the components' distributions differently, in ways consistent with the identification strategy, helps bolster confidence in both the strategy and the existence of grease and sand effects.

\section{Regression Results}

In this section, we further examine links between price changes and the variability of the $\beta$ and $\gamma$ vectors (the firm and occupational coefficients estimated in equation [1] and summarized in table 4), through regressions of their employer/occupation-cell weighted standard deviations on the level of inflation. The sand and grease hypotheses predict that the standard deviations of the $\beta$ and $\gamma$ vectors (respectively) increase with the level of inflation. A priori, we also expect the standard deviation of occupational wage changes to be bounded by the size of usual shocks to the labor market, whereas disruptive 
firm variation may be unbounded under high inflation. ${ }^{12}$ The regressions reported in this section all take the following form:

$$
{ }_{\text {stdem }_{t}}^{\text {stdoc }_{t}}=\psi+\phi_{1}(\Delta X)_{t}+\phi_{2}(\Delta X)_{t}^{2},
$$

where $s t d o c_{t}$ and stdem $_{t}$ (occupation and employer wage-change dispersion, respectively) are regressed independently on some proxy (or proxies) for annual wage movement, represented here by $\Delta X .{ }^{13}$ The simple two-term quadratic expansions allow curvature in these estimates, while remaining easily interpretable. To further aid interpretation, the bottom row of each table also reports the implied value of the independent variable at the maximum.

After considering the impact of expanding the sample, we compare a variety of specifications. Then we consider the likelihood that inflation might aid the intended adjustment of firm (rather than occupation) wage differentials.

\section{a. The Effect of Sample Extension}

Table 5 shows the impact of the new observations, using the $C P I+$ measure of external nominal wage change. The first and third columns report basic regression results from the original Groshen and Schweitzer (1996) sample. The second and fourth columns report results from the extended sample.

The qualitative results (inverted U-shaped relationships, with an earlier peak for occupation) are unchanged, but some interesting effects are evident. First, the employer (sand) effect now peaks at an even higher inflation rate, while the occupation (grease) effect tops out at slightly lower inflation rate than before. Thus, the contrast between the two is more marked. Second, however, the explanatory power $\left(\mathrm{R}^{2}\right)$ of both equations has fallen (particularly for the occupation/grease effect) suggesting that extrapolations from the quadratic form may not fit well at the current low inflation rates.

(1986).

12 Expanding indexation could bound the sand effect, as suggested by Drazen and Hamermesh

${ }^{13}$ While the two-stage nature of this procedure may raise standard errors in equation (2), it will not influence coefficient estimates unless the first-stage estimation errors are correlated with our measures of inflation. We have no a priori reason to suspect such a correlation. 
Figures $3 \mathrm{~A}$ and $3 \mathrm{~B}$ plot the new estimated relationships, along with nonparametric (smoothed) versions of the same relationships. ${ }^{14}$ The smoothing is similar to allowing a large number of quadratic terms, and continues to suggest that the parsimonious models in table 5 capture most of the curvature in these relationships. The frequency of observations is indicated (except for overlaps) by the density of tick marks for the smoothed estimates.

The two figures also show tick marks for the new observations. In figure $3 \mathrm{~B}$, the marks are concentrated far above the predicted relationship. This pattern indicates that interoccupational wage flexibility has consistently exceeded the levels that would be expected by extrapolation off the historical relationship. No similar evidence is noticeable for employer adjustments in figure 3A. These results support the hypothesis that downward wage rigidity has relaxed recently in large employers -- precisely the segment of the labor market where wages would tend to be the most rigid.

\section{b. Freeing the Coefficients on CPI and Productivity}

Use of $C P I+$ in the regressions in table 5 imposes the same coefficient on productivity and inflation. While theory provides a strong rationale for this approach, the restriction is empirically testable. One practical reason to suspect a difference in estimated relationships is that productivity is highly variable and arguably measured with a great deal of error. Thus, when freed up, we expect coefficients on output per hour to be biased toward zero and have high standard errors. Table 6 reports results for some variants that separate the two underlying series.

The first specification repeats $C P I+$ results from table 5, for comparison purposes. The second shows the impact of separating the two series in quadratic form. Employer wage-change dispersion is no better modeled with the terms separate than together, while the separation more than doubles the adjusted $\mathrm{R}^{2}$ of the model of occupational adjustments. But, the third specification (CPI-U and its square alone) suggests that in both cases, the shape of the relationship is mostly determined by inflation -- output per

\footnotetext{
14 We use the LOWESS smoother with a bandwidth of one, recommended by Cleveland (1979), for its robustness with respect to both axes. Various bandwidths for 0.2 to 1 were tried, with little variation
} 
hour contributes little extra. The implied maxima shown at the bottom suggest that it is in their relationship to the $\mathrm{CPI}-\mathrm{U}$ that the employer and occupation adjustments differ most strikingly.

The final model shown takes an intermediate approach. It assumes that the difference between the results for output per hour and CPI-U stems mostly from poor output measurement. In both cases, the fit improves and the coefficient is negative, suggesting that the term may absorb some of the downward bias caused by productivity mismeasurement.

These decompositions of the impact of mean nominal wage change are consistent with poor measurement of productivity growth. Since the problem is not easy to fix, and theory is unambiguous about productivity's role in generating grease, we continue to prefer specifications that include both inflation and productivity changes.

\section{c. Adding Controls for Trend and Unemployment}

Cyclical factors or secular trends could augment the level of employer wagechange dispersion or the pace of occupational adjustment, and these could be correlated with measures of inflation. Thus, table 7 reports the result of adding controls for time trend and the unemployment rate.

The first specification repeats the results from the last specification of table 6 , for comparison purposes. The second adds a time trend and its square. While taking account of the trend improves the fits substantially (by about double), the implied maxima and the shape of the $C P I+$ relationships are stable -- the grease and sand effects are independent of the trends. The estimated coefficients on trend imply that the average pace of adjustments in both these components is rising. For the occupation component, this result suggests growing wage flexibility or, perhaps, increased frequency or size of shocks. Ultimately, such changes would be expected to alter grease and/or sand relationships.

Results of adding the unemployment rate vary more between components. Employer wage-change dispersion is unaffected by the unemployment rate: fit worsens and the sand coefficients are unchanged. While the grease coefficients are also

in effect. 
unchanged, occupational adjustments clearly respond strongly to cyclical factors, pointing to another intriguing difference in behavior between the occupation and employer components.

This result rules out a compositional interpretation of our findings. Reder (1955) argues that employers hire lower-quality workers during expansions than recessions. If three additional conditions hold (i.e., low-quality workers receive lower wage changes within cell, inflation level and unemployment rate are negatively correlated, and these quality differences vary by employer and/or occupation), our results could reflect systematic variations in worker quality. However, if this was the correct interpretation of our results, then including the jobless rate -- a better measure of labor market conditions - should reduce the size and significance of the estimated coefficients on CPI+. The strong association between occupational adjustments and joblessness supports Reder's hypothesis. Nevertheless, unemployment's lack of impact on the grease coefficients constitutes strong evidence that this hypothesis cannot explain our results.

Thus, while trend and cyclical factors influence the variance of both components of wage adjustments, their omission does not appear to bias the grease and sand estimates. This result increases our confidence in the grease and sand interpretation of our findings and justifies our preference for the parsimonious basic model for exposition.

\section{d. Inflation Surprises Versus Expected Inflation}

The grease effect results from the leeway provided by expected or experienced inflation, but not by inflation surprises. On the other hand, price-level surprises are sufficient to cause the sand effect in the presence of timing rigidities. Thus, separating expected inflation from surprises provides another check on the identification strategy. $A$ priori, we expect occupation wage-change variation to rise mostly with expected inflation. Inflation surprises should have their primary effect on employer wage adjustments.

Our measure of firms' inflation expectations is the (beginning-of-the-period) University of Michigan Surveys of Consumers' mean inflation expectations. This series 
provides a consistent measure over the entire sample period and has been shown to be an unbiased predictor of future price increases (Bryan and Gavin, 1986).

Table 8 splits the grease and sand effects between expectations and surprises. The first model repeats results from the third column of table 6 , for comparison purposes. The second, third, and fourth models show the impact of expected and surprise inflation separately and together. Looking at the significance of the coefficients, the $\mathrm{R}^{2} \mathrm{~s}$, and the implied maxima, the results are quite stark. As predicted, a surprise sharply raises employer wage-change dispersion, whereas expectations dominate for the occupational adjustments. Also, the expected/surprise distinction clearly improves the fit of the employer regression, while contributing no explanatory power for occupational adjustments. Finally, these estimates strongly suggest that the sand effects caused by inflationary surprises may be unbounded, while any impact on occupational adjustments is quickly exhausted.

Because they are very difficult to explain otherwise, these results provide particularly strong support for the grease and sand interpretation of our findings.

\section{e. Might Inflation Also Speed Intended Firm Adjustments?}

An important possibility to consider is whether employers' inflation-induced wage adjustment variation may be intentional, rather than sand. This would be the case if inflation allowed firms more scope to reduce average wage differentials in response to negative shocks. For example, they might intend to induce quits to allow shrinkage, or to reduce shared rents. We consider such an interpretation inconsistent with our findings for the following reasons.

First, prior studies lead us to expect sand effects among firms. The sand literature for product markets finds consistent evidence of inflation induced price-change variation (for the closest example see Lach and Tsiddon, 1992). If inflation has no similar effect on wages, information must be better in labor markets, or menu costs or other sources of rigidity must be lower. None of these is likely. Certainly if better inflation forecasts were available in corporate personnel offices, it would be shared with their sales offices. Menu costs in salary administration are high enough that salaries are rarely reviewed more than 
annually, while many product prices are changed much more often. So, there is good reason to expect a sand effect for wages among firms.

Second, the circumstances under which inflation would play a grease role between firms are quite limited. As we discuss above, it is unusual for a firm to want to change its market position. Indeed, in these data, autocorrelations for employers' fixed wage effects one and ten years apart are 0.93 and 0.62, respectively (Groshen and Levine, 1997). Most effort is directed at maintaining, not adjusting, the market position. However, firms under severe duress do cut nominal wages (Bewley and Brainard, 1993; Blinder and Choi, 1990; and Levine, 1993). Thus, the conditions under which a firm would resort to using inflation to adjust relative wages are rather narrow: a shock large enough to fundamentally alter its labor market strategy, but not big enough for it to openly admit the problem and cut nominal wages.

Even then, it is unclear why a firm in these intermediate circumstances would reduce wages for all workers (risking a general decline in effort) rather than those of the particular occupations it needed to shed.

If, however, such circumstances were common enough to drive many of firms' inflation-induced wage changes in the CSS, then there would be no reason to expect markedly different employer and occupation wage responses to inflation. For example, the effect of inflation on wage-change densities and standard deviations should be similar for the two components, not distinctly different. In particular, since downward wage rigidity would be a factor, we should see evidence of truncation in the low-inflation employer density in figure $2 \mathrm{~A}$-- which we do not. Also, the later peak in firms' standard deviation regressions would be unexpected. Finally, inflation surprises should not raise firm wage-change variation at all -- let alone more than expected inflation.

Thus, labor market sand effects are anticipated and the circumstances under which inflation would relax a constraint imposed by downward wage rigidity on firm differentials are likely to be rare. Indeed, if they are not rare, we have a puzzle: what explains the striking differences between employer and occupation adjustment patterns under inflation? By contrast, these differences are fully explicable, indeed expected, under the identification strategy. Therefore, our findings are consistent with a sand 
interpretation for inflation-induced firm wage shifts and inconsistent with a grease interpretation.

\section{Implications of Results}

This section considers the net impact of inflation on the economy. We motivate the question by examining the aggregate relationship between inflation and joblessness. Next we present two approaches to estimating the extent to which grease and sand effects estimated here offset each other. Finally, we contrast our approaches and conclusions with those contained in two recent studies of inflation's grease effect.

\section{a. The Aggregate Relationship Between Inflation and Unemployment}

As a first pass at considering the net impact of grease and sand we plot the aggregate relationship between inflation and unemployment. While other factors beyond grease and sand undoubtedly influence this relationship, it is useful to apprise ourselves of the historical correspondence in the US before proceeding to more direct estimates of the net impact of inflation on unemployment. In particular, has higher inflation been associated with lower US unemployment--as would be the case, ceteris paribus, if the grease effect dominated the sand effect? Or higher joblessness, if sand effects dominate?

Figure 4 plots US civilian unemployment against CPI+ from 1956 though 1996. The fitted regression line makes it clear that what little relationship exists between the two series suggests that more inflation is associated with higher, not lower, rates of unemployment. This aggregate relationship is fully consistent with the results obtained here and with long-run cross-country correlations of GDP growth and inflation across OECD countries (Andres and Hernando, 1997).

However, figure 4 stands in direct contradiction to the predictions of grease-only estimates. Thus, the grease effect must either be offset by sand -- as our findings suggest -- or small relative to other factors that drive the relationship between unemployment and inflation. 


\section{b. Net Impact of Grease and Sand Effects -- General Approach}

We offer two ways to translate our results into an indication of inflation's net impact on the economy. The first approach derives from the assumption that employers find any deviation from their intended wage rates costly, both in ways that increase the unemployment rate and in ways that do not. The second way simulates unemployment consequences of the two effects, for comparability to previous studies.

Our first approach uses inflation-induced wage variation to measure the welfare consequences of inflation. The reasoning follows directly from the model used in Groshen and Schweitzer (1996) and has the advantage of including the full range of impacts on firms. Whatever their source (lack of grease or too much sand), variations from intended wage changes are costly for firms. If the wages are too high, these costs take the form of decreased profits, retained earnings, or investment, or lower production and market share (as the result of laying off overpaid workers). If wages are set too low, the costs come from undesired turnover, extended vacancies, or lower morale and productivity. For firms and workers the losses from mispricing are symmetric across the two effects. That is, the impact differs by whether the deviation is up or down, but not by whether its source is lack of grease or too much sand. Hence, the two impacts of inflation can be compared if they are measured equally well, in the same units, in the same market.

Therefore, our first approach simply nets the inflation-induced impacts on wage variation. Figure 5 plots these net benefits using the extended data. The horizontal axis measures inflation (controlling for productivity), while the vertical axis measures the standard deviation of log wage-changes. For grease, sand and net benefits two lines are drawn: a smooth line for the fitted quadratic relationship, and a kinked line for the nonparametric version of the same relationship. The sand (employer) and grease (occupation) lines are identical to those shown in figures 3A and 3B, respectively. Grease effects are taken as positive, while the sand effect is negative (although plotted in the positive quadrant for consistency with figure $3 \mathrm{~A}$ ).

Net benefits are calculated assuming that gross benefits and costs of inflation are zero when the inflation rate is zero, and that productivity growth is 1.5 percent, using the following relationship (suppressing the time subscript): 
$($ Net Benefits $\mid \Delta \operatorname{Prod}=.015)=($ Grease $\mid \Delta \operatorname{Prod}=.015)-(\operatorname{Sand} \mid \Delta \operatorname{Prod}=.015)$

$$
=(\operatorname{stdoc}(C P I+)-\operatorname{stdoc}(.015))-(\operatorname{stdem}(C P I+)-\operatorname{stdem}(.015))
$$

where stdem and stdoc are the predicted standard deviations of the employer and occupation components (using columns 2 and 4 of table 5, respectively).

As in the original sample, these estimates suggest a small net benefit for inflation rates below 5 percent. The peak remains at $2 \frac{1}{2}$ percent, and net benefits at the peak remain an order of magnitude less than gross grease benefits. Bootstrapped standard errors around the net benefits estimate are wide enough that they never rule out a net loss from inflation, or a higher gain. However, they conclusively rule out both equality between gross and net benefits, and flat (rather than declining) net benefits at higher rates of inflation.

From this exercise we conclude that while inflation's net benefits are maximized at low levels of inflation, the impact is modest at best. This is because rising sand effects mostly offset the gross grease benefits, leaving little net improvement. Although this approach to calculating net benefits does not directly map into more common metrics, such as output or job losses, it has the distinct advantage of accounting for all costs imposed on firms and workers. While some of the above-mentioned costs of unintended wage variation will affect unemployment, others may not. Particularly if workers' human capital is very firm-specific, employers and employees have less incentive to sever relationships over a short-lived deviation. Thus, impacts on profitability, morale, and productivity may well be larger than observed unemployment effects. Hence, as the best summary of our findings, we prefer this formulation, because it does not unduly confine the measurement of impacts.

\section{c. Net Impact of Grease and Sand Effects -- Simulated Unemployment}

However, for policy purposes and for comparison with previous studies, an estimate of the unemployment impact of the grease and sand effects measured in the CSS is desirable. This section first explains why such an estimate cannot be derived directly from the CSS, and then describes the simulation we use to address the question. 
The statistical model in Groshen and Schweitzer (1996) is designed to detect wage rigidity and uncertainty effects, not employment impacts. Several of the model's features are not suited to a direct translation of our results into joblessness. First, the structure of the data does not allow a reliable measurement of aggregate employment effects. For example, in most years the population of workers in the occupation cells is unknown. Second, the identification strategy does not completely determine all sources of wage variation. Indeed, the approximately 70 percent of wage-change variation remaining in the residual might include unidentified grease and sand effects. Third, unemployment depends on total wage deviations from equilibrium wages, so all components should be accumulated before any impact can be discerned. Thus, unemployment effects cannot be estimated directly from the CSS. However, the parameters of the CSS can be used to craft a simulation that illuminates unemployment effects.

To clarify the underlying source of wage change variation that could account for data like the CSS, we generate artificial data consistent with key features of the CSS. The Appendix describes the simulation in more detail. The simulated data mimic the CSS in three dimensions: an identical firm, occupation, city structure; the same levels of overall variation by year, city, occupation, firm, and residual; and, regression coefficients approximately matching those in the CSS.

Having simulated the data, we next build on the assumption that job losses occur when grease or sand effects drive workers' final wage changes away from equilibrium. The size and frequency of these deviations (combined with elasticities of labor demand and supply) determine the unemployment rate. For truncated wage-changes, only the labor demand elasticity comes into play, because truncation can only raise wage adjustments. Drawing on Hamermesh (1993), we apply a range of uncompensated demand elasticities from -0.1 to -0.5 . For sand effects, which can be either positive or negative, supply elasticities also matter. We use uncompensated labor supply elasticities from 0.0 to 0.6 , reflecting widely-varying implied estimates when both men and women are in the market (Pencavel, 1986; Killingsworth and Heckman, 1986).

Figure 6 shows simulated total unemployment effects of inflation due to grease and sand. The horizontal axis measures $C P I+$, while the vertical axis reports percentage 
points of unemployment. The data are sparse at high and low inflation. Therefore, ends of the curves are determined by the average effect for extreme observations, which are plotted as corresponding to the average lowest and highest $C P I+$ values of 2.8 and 11.8 percent, respectively. ${ }^{15}$ Note that a $C P I+$ value of 2.8 percent corresponds to a very low rate of inflation (near one percent), once productivity growth of 1.5 percent (the average over this period) and any positive biases in the CPI are accounted for.

Over the range that inflation has net beneficial effects, the line will slope down: the steeper the slope, the greater the benefits. Net disruptive effects will be seen as a positive slope. The five lines on the figure correspond to different assumed supply and demand elasticities. As a baseline, we consider a symmetric case (0.3 labor supply elasticity, -0.3 labor demand elasticity), seen as the line with squares in figure 6 . At low rates of inflation, the downward wage rigidity underlying the grease effect causes unemployment. As inflation rises, the grease effect lowers unemployment. However, inflation also raises sand-induced joblessness. Thus, the line shows a mild U-shape. Over the downward sloping portion (from CPI+ of 2.8 to 6 percent), there is little net unemployment impact (less than 0.1 percentage points) of inflation. Beyond that, the grease-effect unemployment reductions become trivial and sand effects continue to grow. There is no evidence of a strong nonlinearity as inflation gets very low.

Higher elasticities of labor demand raise inflation-related unemployment because employers are more likely to lay off workers in response to higher-than-notional wages (see the line for supply elasticity of 0.3 and demand elasticity of -0.5). The net effect line shifts up fairly uniformly because both grease and sand effects rise, leading to more unemployment at high and low levels of inflation. The slope of the line (which is the net effect of additional inflation on unemployment) remains almost flat, except at high levels.

Labor supply elasticity, on the other hand, affects only sand-induced joblessness. More elastic supply emphasizes the sand effects. The less elastic is supply, the smaller the sand effect, so grease effects dominate. However, even the extreme example shown

\footnotetext{
15 To construct these endpoints, we aggregate all observations with CPI+ of less that 3.5 or more than 9.5 and estimated mean grease and sand effects. In figure 6, these mean effects are assigned to CPI+ values of 2.9 and 11 percent, respectively -- because these are the mean CPI+ values for the extreme observations.
} 
in figure 6 (perfectly inelastic supply with demand elasticity of -0.3) generates only a 0.2 percentage point drop in unemployment for a 5 percentage point increase in inflation (from $C P I+$ of 2.8 to 8.0 ).

To sum up: In this section we simulate a wage-change generating process modeled on the structure of the CSS. Simulated observations allow us to estimate unemployment impacts of grease and sand. The exercise shows that even under extreme assumptions about the elasticities of labor demand and supply, grease and sand effects almost fully offset each other at low to moderate rates of inflation. In particular, under a wide range of elasticities of labor supply and demand, we find no evidence that very low rates of inflation raise unemployment noticeably.

\section{d. Comparison of Results With Recent Wage Rigidity Studies}

How do these results compare with recent studies of inflation's effect on wagesetting? We focus on Akerlof, Dickens, and Perry (1996) [AD\&P] and Card and Hyslop (1995) $[\mathrm{C \& H}]$, since they are very recent studies. ${ }^{16}$

We begin by listing three important ways in which our work differs from both studies. First, neither AD\&P nor C\&H considers offsetting sand effects. Second, our analysis and model are tightly linked to actual wage adjustment procedures. Our firmlevel data allow us to identify and interpret wage rigidities unobservable in household surveys. Third, neither study analyzes micro-level wage changes spanning the range of years (and thus, the range of inflation rates) covered in the CSS. In particular, neither study includes low-inflation years in the 1950s, 1960s and 1990s. Thus, implications they derive about low inflation are largely out-of-sample extrapolations.

Nevertheless, broadly speaking, our empirical results for the grease effect are consistent with findings in both studies: downward wage rigidity binds more at low rates of inflation, so higher inflation has some beneficial gross effects. We now contrast our study with the two others in turn.

\footnotetext{
16 Other fairly recent studies of the grease effects include Kahn (1995); McLaughlin (1994) and Lebow, Stockton, and Wascher (1993). All three perform micro-level tests of downward wage rigidity.
} 
AD\&P has three main sections. The first examines wide-ranging, new and old empirical evidence of downward nominal wage rigidity. Next, it models and emulates grease affects to show that (for plausible values of parameters) this rigidity could raise unemployment substantially at low inflation rates. Third, it converts the simulation model to one that can be estimated on aggregate data, and shows that out-of-sample predictions from the model can emulate Depression-era unemployment patterns. Thus, $\mathrm{AD} \& \mathrm{P}$ concludes that low inflation is very costly in the labor market.

In the empirical section, AD\&P considers the spike at zero in the density of wage changes to be key evidence of downward wage rigidity. We argue that while the spike is a likely prediction, it may not be either necessary or sufficient. It is not necessary evidence if constrained workers are laid off. It is not sufficient because zero is a double rounding point (in even dollars and percentage points), potentially creating a large spurious concentration at zero. For those reasons, we consider inflation's impact on wage-change variation a preferable measure (particularly in the CSS, which does not report individual wages). Nevertheless, our findings agree with AD\&P's qualitative conclusion that the grease effect exists.

The contrast with our study centers on unemployment effects in our simulation exercises. The marked difference in conclusions reflects divergent structures for wagechange variation. To explicitly consider the effect of errors and other randomness, we observe and, thus, generate firm-based wage variation $(0.036 \log$ points when $C P I+$ is 5 percent) that rises with inflation, plus a constant residual variation (0.080 log points). To reflect persistent market shocks, we add constant occupation variation (0.028 log points). By contrast, AD\&P's underlying structure is constant with respect to inflation, has a single component (the firm) and generates a much smaller standard deviation of log wage-changes (0.028) than we observe in the CSS. AD\&P's firm effects are most comparable to our occupation effects in size and in variance with inflation. Their demand shocks affect firms, while ours act on both firms and skills. Thus, AD\&P implicitly assumes that there are no distinct occupational markets, or that firms employ only one occupation at a time. 
The AD\&P simulation also assumes a fairly high rate of truncation for constrained wages -- not much different from ours. At low rates of inflation, the CSS data on which we base our simulation show no sign of nonlinearity. By contrast, AD\&P's extrapolated simulation produces a highly non-linear region at low inflation rates. Indeed, this is the range on which they base their strongest policy conclusions.

$\mathrm{C} \& \mathrm{H}$ performs a more detailed analysis of the effect of wage rigidity in the March Current Population Survey (CPS), 1979 to 1993, and the Michigan Panel Study of Income Dynamics (PSID), 1976 to 1979 and 1985 to 1988. They consider the impact that wage rigidity would have on the distribution of changes, accounting for errors and rounding. Then they generate a counterfactual, unconstrained distribution to gauge the effects of wage rigidity. Despite some assumptions that might bias down their estimated effect, they detect evidence of substantial wage rigidity under low inflation. In contrast to the CSS sample used here, $\mathrm{C} \& \mathrm{H}$ has no information on firms and few low-inflation years.

The final part of $\mathrm{C} \& \mathrm{H}$ detects little or no macro impact of a net grease effect at the market level. A state-level comparison of the relationship between nominal wage changes and unemployment (using CPS files from 1976 to 1992) yields only a small, statistically insignificant relationship. Although C\&H offer little explanation for the apparent contradiction between their individual and aggregate results, their findings can be easily explained by the existence of the sand effect which they do not measure at the micro level. Indeed, their findings, if not their interpretations, are compatible with those presented above.

Thus, the evidence for the grease effect in the CSS is consistent with micro-level findings in $\mathrm{AD} \& \mathrm{P}$ and $\mathrm{C} \& \mathrm{H}$. In addition, our simulated unemployment results can explain the lack of relationship between inflation and state-level unemployment rates found in $\mathrm{C} \& \mathrm{H}$. By contrast, our findings suggest that the AD\&P simulations -- which predict a strong unemployment cost for low inflation -- appear to be largely an artifact of extrapolation in a model that ignores sand effects. 


\section{Conclusions}

Our companion study finds evidence that inflation stimulates both beneficial intermarket and distortionary intramarket wage changes. The identification strategy for this conclusion is that inflation-induced occupational adjustments represent beneficial grease, while inflation-induced wage-changes among employers reflect distortionary sand in the labor market. This paper examines forty years of CSS data in order to judge the appropriateness of this key identification strategy. We also check whether downward wage rigidity has relaxed in recent years, reducing our need for inflation's grease.

One form of support for the assumption is that many important institutional features of the wage-setting process accord well with the formal model used to generate the hypotheses tested. In addition, we present a variety of independent empirical findings that all provide further support. Table 9 summarizes these findings. Probes 4 and 5 are more fully described in our companion paper. The others are presented above.

No single probe can be fully convincing on its own. However, the combined weight of these varied findings sustain the validity of the identification strategy. Indeed, these findings (such as inflation expectations being the sole source of the inflationinduced occupation effects, while surprises matter more for employer effects) are very difficult to explain if the strategy is not valid. Thus, the grease and sand interpretation of inflation-induced occupation and employer wage adjustments holds up well to close scrutiny.

The second question -- whether wage rigidity has relaxed in recent years -- finds the following support:

- The pace of occupational wage adjustments in the past years is consistently much higher than would be predicted, based on the historical relationships and the current level of inflation. The same does not hold true for employer wage-change dispersion.

- Over time, occupational wage-change dispersion shows a statistically significant upward trend, with a lot of explanatory power. While this is also true among employers, it explains much less variation over time.

Although it would be premature to claim that this evidence constitutes proof of the US economy's reduced need for inflationary grease, our findings do point in that direction. This result is particularly intriguing because large firms are precisely the segment of the 
labor market where wages are thought to be most rigid. More research is clearly warranted in this area.

What implications do these findings have for policy? Both buttress the conclusion that low-inflation regimes may not raise unemployment or impair the smooth functioning of labor markets. Even if one accepts previous estimates of the grease effect at full face value, our results suggest that the net labor market benefits of inflation are an order of magnitude smaller, because of inflation's simultaneous sand effect. And they may be shrinking further. Thus, the labor market provides little guidance on which inflation goal to choose in a low-inflation regime. 
Table 1

\section{Description of the Annual Wage Adjustment Data Set Drawn from the Updated CSS, 1956-1996}

Total Number of Job-Cell Wage Adjustments Observed $\quad$ 75,765

Number of Years of Changes $\quad 40$

Average Number of Observations Per Year $\quad 1,894$

$\begin{array}{ll}\text { Mean Log Wage Adjustment } & 0.048\end{array}$

Standard Deviation of Log Wage Adjustment $\quad 0.084$

Number of Occupation*City*Year Observations $\quad 6,187$

Avg. No. of Occupation*City Observations Per Year 155

$\begin{array}{ll}\text { Number of Employer-years } & 3,002\end{array}$

Average Number of Employers Per Year 75

Note: All numbers reported are for the first-differenced data set.

Source: Authors' calculations from the Federal Reserve Bank of Cleveland Community Salary Survey. 
Table 2

Description of CSS Data by Year

\begin{tabular}{|c|c|c|c|c|c|c|}
\hline \multirow{2}{*}{$\begin{array}{l}\text { End } \\
\text { Year }\end{array}$} & \multicolumn{3}{|c|}{ Number of: } & \multicolumn{3}{|c|}{ Mean Log Wage Adjustment in: } \\
\hline & Job cells & Occupations* & Employers & Cleveland & Cincinnati & Pittsburgh \\
\hline 1957 & 1,336 & 94 & 73 & 0.051 & 0.046 & 0.045 \\
\hline 1958 & 1,557 & 94 & 83 & 0.049 & 0.054 & 0.050 \\
\hline 1959 & 1,714 & 103 & 88 & 0.040 & 0.048 & 0.070 \\
\hline 1960 & 1,669 & 103 & 86 & 0.036 & 0.032 & 0.034 \\
\hline 1961 & 1,701 & 103 & 88 & 0.039 & 0.035 & 0.036 \\
\hline 1962 & 1,881 & 109 & 93 & 0.024 & 0.022 & 0.024 \\
\hline 1963 & 1,910 & 112 & 90 & 0.019 & 0.026 & 0.024 \\
\hline 1964 & 2,032 & 113 & 96 & 0.026 & 0.022 & 0.023 \\
\hline 1965 & 2,123 & 124 & 95 & 0.021 & 0.026 & 0.010 \\
\hline 1966 & 1,965 & 125 & 89 & 0.040 & 0.045 & 0.038 \\
\hline 1967 & 1,967 & 125 & 89 & 0.037 & 0.042 & 0.035 \\
\hline 1968 & 2,128 & 124 & 94 & 0.046 & 0.044 & 0.042 \\
\hline 1969 & 1,972 & 114 & 97 & 0.066 & 0.050 & 0.049 \\
\hline 1970 & 853 & 49 & 36 & 0.068 & $* *$ & $* *$ \\
\hline 1971 & 854 & 49 & 36 & 0.061 & $* *$ & $* *$ \\
\hline 1972 & 1,262 & 66 & 38 & 0.061 & $* *$ & $* *$ \\
\hline 1973 & 1,477 & 90 & 57 & 0.056 & 0.095 & $* *$ \\
\hline 1974 & 1,335 & 96 & 73 & 0.126 & 0.084 & 0.139 \\
\hline 1975 & 1,379 & 101 & 73 & 0.074 & 0.063 & 0.090 \\
\hline 1976 & 1,391 & 104 & 72 & 0.065 & 0.057 & 0.078 \\
\hline 1977 & 789 & 60 & 72 & 0.030 & 0.021 & 0.052 \\
\hline 1978 & 1,674 & 197 & 68 & 0.052 & 0.063 & 0.066 \\
\hline 1979 & 2,418 & 267 & 75 & 0.064 & 0.071 & 0.069 \\
\hline 1980 & 2,689 & 295 & 79 & 0.095 & 0.074 & 0.087 \\
\hline 1981 & 2,196 & 186 & 83 & 0.086 & 0.089 & 0.059 \\
\hline 1982 & 2,185 & 193 & 82 & 0.072 & 0.092 & 0.078 \\
\hline 1983 & 2,013 & 190 & 75 & 0.050 & 0.055 & 0.073 \\
\hline 1984 & 2,274 & 213 & 80 & 0.047 & 0.058 & 0.063 \\
\hline 1985 & 2,272 & 212 & 79 & 0.040 & 0.044 & 0.042 \\
\hline 1986 & 2,396 & 220 & 82 & 0.042 & 0.044 & 0.037 \\
\hline 1987 & 2,437 & 226 & 80 & 0.031 & 0.037 & 0.038 \\
\hline 1988 & 2,401 & 222 & 82 & 0.036 & 0.037 & 0.023 \\
\hline 1989 & 2,407 & 225 & 81 & 0.045 & 0.041 & 0.036 \\
\hline 1990 & 2,505 & 222 & 84 & 0.052 & 0.046 & 0.024 \\
\hline 1991 & 2,536 & 223 & 89 & 0.038 & 0.045 & 0.035 \\
\hline 1992 & 2,398 & 223 & 84 & 0.039 & 0.042 & 0.043 \\
\hline 1993 & 2,355 & 223 & 89 & 0.032 & 0.026 & 0.040 \\
\hline 1994 & 2,128 & 223 & 84 & 0.027 & 0.029 & 0.025 \\
\hline 1995 & 1,841 & 241 & 69 & 0.027 & 0.031 & 0.019 \\
\hline 1996 & 1,345 & 240 & 51 & 0.040 & 0.032 & 0.030 \\
\hline Total & 75,765 & 6,187 & 3,002 & 0.049 & 0.048 & 0.048 \\
\hline
\end{tabular}

* Occupations are counted separately for each city.

** In 1970-72, the CSS is missing Cincinnati; in 1970-73, the CSS is missing Pittsburgh.

Source: Authors' calculations from the Federal Reserve Bank of Cleveland Community Salary Survey, 1956-1996. 
Table 3

\section{Means and Standard Deviations of CSS Wage Adjustment Components and Other Economic Indicators}

\begin{tabular}{|lcc|}
\hline \multicolumn{1}{|c}{ Variable } & Mean & $\begin{array}{r}\text { Standard } \\
\text { Deviation }\end{array}$ \\
\hline $\begin{array}{l}\text { Standard Deviation of Employer } \\
\text { Wage Adjustment Components }\end{array}$ & 0.030 & 0.011 \\
$\begin{array}{l}\text { Standard Deviation of Occupation } \\
\text { Wage Adjustment Components }\end{array}$ & 0.023 & 0.009 \\
Current US CPI-U & & \\
$\Delta$ Output/Hour $^{\mathrm{b}}$ & 0.046 & 0.034 \\
CPI+ (CPI-U $^{\mathrm{a}}+\Delta$ Output/Hour $\left.^{\mathrm{b}}\right)$ & 0.062 & 0.026 \\
Unemployment Rate $^{\mathrm{c}}$ & 0.016 & 0.018 \\
Expected Inflation $^{\mathrm{d}}$ & 0.061 & 0.014 \\
Inflation Surprise $^{\mathrm{e}}$ & 0.046 & 0.024 \\
\hline
\end{tabular}

${ }^{\mathrm{a}}$ The annual change in the BLS Consumer Price Index for all Urban Workers (CPI-U) for the US.

The annual change in the BLS Nonfarm Business Sector Output per Hour Worked for the US.

${ }_{d}^{c}$ US civilian unemployment rate.

Taken from the Michigan Survey of Inflation Expectations.

${ }^{\mathrm{e}} \mathrm{CPI}-\mathrm{U}$ minus expected inflation.

Note: Total number of observations: 113.

Sources: Authors' calculations from the Federal Reserve Bank of Cleveland Community Salary Survey, 1956-1996. US Bureau of Labor Statistics. Michigan Survey. 
Table 4

\section{ANOVA of Annual Wage Adjustments in the CSS, 1957-1996}

\begin{tabular}{|lrrrrr|}
\hline $\begin{array}{l}\text { Source of } \\
\text { Variation }\end{array}$ & $\begin{array}{c}\text { Degrees } \\
\text { of } \\
\text { Freedom }\end{array}$ & $\begin{array}{c}\text { Marginal } \\
\text { Contribution } \\
\text { to Sum of } \\
\text { Squares }\end{array}$ & $\begin{array}{c}\text { Percent } \\
\text { of Total } \\
\text { Sum of } \\
\text { Squares }\end{array}$ & $\begin{array}{c}\text { Percent } \\
\text { of Model } \\
\text { Sum of } \\
\text { Squares }\end{array}$ & $\begin{array}{r}\text { Stepwise } \\
\text { F-Statistic }\end{array}$ \\
\hline City & 2 & 0.3 & 0.0 & 0.1 & 12.3 \\
Year & 39 & 30.6 & 5.8 & 21.1 & 119.7 \\
Year*City & 71 & 3.4 & 0.6 & 2.3 & 7.2 \\
Occ*Year*City & 6,186 & 45.2 & 8.5 & 31.1 & 1.2 \\
Employer*Year & 3,001 & 65.9 & 12.4 & 45.4 & 4.3 \\
Model & 9,299 & 145.3 & 27.4 & 100.0 & \\
Residual & 66,465 & 385.2 & 72.6 & & \\
Total & & & & & \\
\hline
\end{tabular}

*The three cities are Cleveland, Cincinnati, and Pittsburgh. The years are 1956-1957 through 19951996.

Source: Authors' calculations from the Federal Reserve Bank of Cleveland Community Salary Survey. 
Table 5

Basic Regressions of the Standard Deviation of Employer and Occupation Wage Adjustments on Wage Inflation: Original and Extended Samples

\begin{tabular}{|c|c|c|c|c|}
\hline \multirow[b]{3}{*}{ Model } & \multicolumn{4}{|c|}{$\begin{array}{l}\text { Dependent Variable -- Standard Deviation of Wage } \\
\text { Adjustment Components: }\end{array}$} \\
\hline & \multicolumn{2}{|c|}{ Employer } & \multicolumn{2}{|c|}{ Occupation } \\
\hline & 1957-1992 & 1957-1996 & 1957-1992 & 1957-1996 \\
\hline Intercept & $\begin{array}{c}0.012 \\
(0.007)\end{array}$ & $\begin{array}{c}0.015 \\
(0.006)\end{array}$ & $\begin{array}{c}0.004 \\
(0.005)\end{array}$ & $\begin{array}{c}0.007 \\
(0.005)\end{array}$ \\
\hline $\mathrm{CPI+}{ }^{*}$ & $\begin{array}{c}0.394 \\
(0.198)\end{array}$ & $\begin{array}{c}0.323 \\
(0.177)\end{array}$ & $\begin{array}{c}0.458 \\
(0.136)\end{array}$ & $\begin{array}{c}0.427 \\
(0.137)\end{array}$ \\
\hline Squared $C P I+{ }^{*}$ & $\begin{array}{l}-1.475 \\
(1.227)\end{array}$ & $\begin{array}{l}-1.104 \\
(1.120)\end{array}$ & $\begin{array}{l}-2.293 \\
(0.843)\end{array}$ & $\begin{array}{l}-2.301 \\
(0.865)\end{array}$ \\
\hline $\begin{array}{l}\text { Adjusted } \mathbf{R}^{\mathbf{2}} \\
\text { No. of Observations }\end{array}$ & $\begin{array}{c}0.138 \\
101\end{array}$ & $\begin{array}{c}0.121 \\
113\end{array}$ & $\begin{array}{c}0.151 \\
101\end{array}$ & $\begin{array}{c}0.089 \\
113\end{array}$ \\
\hline $\begin{array}{l}\text { F Stat. for joint test, } \\
1 \% \text { cutoff } \leq 4.8\end{array}$ & 9.0 & 8.7 & 9.9 & 6.5 \\
\hline $\begin{array}{l}\text { Implied } C P I+* \\
\text { Maxima }\end{array}$ & $13.4 \%$ & $14.6 \%$ & $10.0 \%$ & $9.3 \%$ \\
\hline
\end{tabular}

*CPI+ is the sum of the annual change in the BLS Consumer Price Index for all Urban Workers (CPI-U) and the BLS Nonfarm Business Sector Output per Hour Worked. Note: Numbers in parentheses are standard errors.

Source: Authors' calculations from the Federal Reserve Bank of Cleveland Community Salary Survey, 1956-1996. 
Table 6

\section{Regressions of the Standard Deviation of Employer and Occupation Wage Adjustments on CPI and Output/Hour Separately}

\begin{tabular}{|c|c|c|c|c|c|c|c|c|}
\hline \multirow[b]{3}{*}{ Model } & \multicolumn{8}{|c|}{ Dependent Variable -- Standard Deviation of Wage Adjustment Components: } \\
\hline & \multicolumn{4}{|c|}{ Employer } & \multicolumn{4}{|c|}{ Occupation } \\
\hline & 1 & 2 & 3 & 4 & 1 & 2 & 3 & 4 \\
\hline Intercept & $\begin{array}{c}0.015 \\
(0.006)\end{array}$ & $\begin{array}{c}0.021 \\
(0.003)\end{array}$ & $\begin{array}{c}0.024 \\
(0.003)\end{array}$ & $\begin{array}{c}0.014 \\
(0.006)\end{array}$ & $\begin{array}{c}0.007 \\
(0.005)\end{array}$ & $\begin{array}{c}0.017 \\
(0.002)\end{array}$ & $\begin{array}{c}0.015 \\
(0.002)\end{array}$ & $\begin{array}{c}0.006 \\
(0.004)\end{array}$ \\
\hline$C P I+{ }^{*}$ & $\begin{array}{c}0.323 \\
(0.177)\end{array}$ & & & $\begin{array}{c}0.403 \\
(0.182)\end{array}$ & $\begin{array}{c}0.427 \\
(0.137)\end{array}$ & & & $\begin{array}{c}0.589 \\
(0.129)\end{array}$ \\
\hline Squared $\mathrm{CPI}{ }^{*}$ & $\begin{array}{c}-1.104 \\
(1.120)\end{array}$ & & & $\begin{array}{l}-1.683 \\
(1.162)\end{array}$ & $\begin{array}{l}-2.301 \\
(0.865)\end{array}$ & & & $\begin{array}{l}-3.480 \\
(0.823)\end{array}$ \\
\hline CPI-U & & $\begin{array}{c}0.119 \\
(0.097)\end{array}$ & $\begin{array}{c}0.136 \\
(0.090)\end{array}$ & & & $\begin{array}{c}0.219 \\
(0.068)\end{array}$ & $\begin{array}{c}0.293 \\
(0.065)\end{array}$ & \\
\hline Squared CPI-U & & $\begin{array}{c}0.456 \\
(0.723)\end{array}$ & $\begin{array}{l}-0.108 \\
(0.570)\end{array}$ & & & $\begin{array}{l}-0.771 \\
(0.513)\end{array}$ & $\begin{array}{l}-1.377 \\
(0.415)\end{array}$ & \\
\hline$\Delta$ Output/Hour & & $\begin{array}{c}0.224 \\
(0.146)\end{array}$ & & $\begin{array}{l}-0.096 \\
(0.057)\end{array}$ & & $\begin{array}{c}0.085 \\
(0.103)\end{array}$ & & $\begin{array}{l}-0.197 \\
(0.040)\end{array}$ \\
\hline $\begin{array}{l}\text { Squared } \Delta \\
\text { Output/Hour }\end{array}$ & & $\begin{array}{l}-3.716 \\
(3.101)\end{array}$ & & & & $\begin{array}{l}-4.559 \\
(2.204)\end{array}$ & & \\
\hline Adjusted $\mathbf{R}^{2}$ & 0.121 & 0.122 & 0.119 & 0.136 & 0.089 & 0.233 & 0.189 & 0.246 \\
\hline $\begin{array}{l}\text { F Stat. joint } \\
\text { test, } 1 \% \text { cutoff } \\
\leq 4.8\end{array}$ & 8.7 & 4.9 & 8.6 & 6.9 & 6.5 & 9.5 & 14.0 & 13.2 \\
\hline $\begin{array}{l}\text { Implied Maxima } \\
\mathrm{CPI}^{*}{ }^{*} \\
\mathrm{CPI} \\
\Delta \text { Output/Hour }\end{array}$ & $14.6 \%$ & $\begin{array}{c}\infty \\
3.0 \%\end{array}$ & $63.0 \%$ & $12.0 \%$ & $9.3 \%$ & $\begin{array}{c}14.2 \% \\
0.9 \%\end{array}$ & $10.6 \%$ & $8.5 \%$ \\
\hline
\end{tabular}

*CPI+ is the sum of the annual change in the BLS Consumer Price Index for all Urban Workers (CPI$\mathrm{U})$ and the BLS Nonfarm Business Sector Output per Hour Worked.

Note: Numbers in parentheses are standard errors. Number of Observations: 113.

Source: Authors' calculations from the Federal Reserve Bank of Cleveland Community Salary Survey, 1956-1996. 
Table 7

\section{Regressions of the Standard Deviation \\ of Employer and Occupation Wage Adjustments on CPI+ with Unemployment and Trend Controls}

\begin{tabular}{|c|c|c|c|c|c|c|}
\hline \multirow[b]{3}{*}{ Model } & \multicolumn{6}{|c|}{ Dependent Variable -- Standard Deviation of Wage Adjustment Components: } \\
\hline & \multicolumn{3}{|c|}{ Employer } & \multicolumn{3}{|c|}{ Occupation } \\
\hline & 4 & 5 & 6 & 4 & 5 & 6 \\
\hline Intercept & $\begin{array}{c}0.014 \\
(0.006)\end{array}$ & $\begin{array}{c}78.899 \\
(34.162)\end{array}$ & $\begin{array}{c}0.013 \\
(0.016)\end{array}$ & $\begin{array}{c}0.006 \\
(0.004)\end{array}$ & $\begin{array}{c}68.852 \\
(20.078)\end{array}$ & $\begin{array}{l}-0.024 \\
(0.010)\end{array}$ \\
\hline CPI+ ${ }^{*}$ & $\begin{array}{c}0.403 \\
(0.182)\end{array}$ & $\begin{array}{c}0.658 \\
(0185)\end{array}$ & $\begin{array}{c}0.407 \\
(0.187)\end{array}$ & $\begin{array}{c}0.589 \\
(0.129)\end{array}$ & $\begin{array}{c}0.471 \\
(0.109)\end{array}$ & $\begin{array}{c}0.589 \\
(0.119)\end{array}$ \\
\hline Squared $C P I+*$ & $\begin{array}{l}-1.683 \\
(1.162)\end{array}$ & $\begin{array}{l}-2.974 \\
(1.155)\end{array}$ & $\begin{array}{l}-1.709 \\
(1.191)\end{array}$ & $\begin{array}{l}-3.480 \\
(0.823)\end{array}$ & $\begin{array}{l}-2.435 \\
(0.679)\end{array}$ & $\begin{array}{l}-3.593 \\
(0.761)\end{array}$ \\
\hline$\Delta$ Output/Hour & $\begin{array}{l}-0.096 \\
(0.057)\end{array}$ & $\begin{array}{l}-0.185 \\
(0.059)\end{array}$ & $\begin{array}{l}-0.096 \\
(0.058)\end{array}$ & $\begin{array}{l}-0.197 \\
(0.040)\end{array}$ & $\begin{array}{l}-0.147 \\
(0.034)\end{array}$ & $\begin{array}{l}-0.209 \\
(0.039)\end{array}$ \\
\hline Trend & & $\begin{array}{c}0.084 \\
(0.036)\end{array}$ & & & $\begin{array}{c}0.073 \\
(0.021)\end{array}$ & \\
\hline $\begin{array}{l}\text { Squared } \\
\text { Trend/1000 }\end{array}$ & & $\begin{array}{c}0.022 \\
(0.010)\end{array}$ & & & $\begin{array}{c}0.019 \\
(0.006)\end{array}$ & \\
\hline Unemployment & & & $\begin{array}{c}0.037 \\
(0.436)\end{array}$ & & & $\begin{array}{c}0.813 \\
(0.279)\end{array}$ \\
\hline $\begin{array}{l}\text { Squared } \\
\text { Unemployment }\end{array}$ & & & $\begin{array}{l}-0.344 \\
(3.361)\end{array}$ & & & $\begin{array}{l}-4.821 \\
(2.149)\end{array}$ \\
\hline Adjusted R $\mathbf{R}^{2}$ & 0.136 & 0.223 & 0.120 & 0.246 & 0.534 & 0.374 \\
\hline $\begin{array}{l}\text { F Stat. joint test, } \\
1 \% \text { cutoff } \leq 4.8\end{array}$ & 6.9 & 7.4 & 4.0 & 13.2 & 26.7 & 14.4 \\
\hline $\begin{array}{l}\text { Implied } C P I+{ }^{*} \\
\text { Maxima }\end{array}$ & $12.0 \%$ & $11.1 \%$ & $11.9 \%$ & $8.5 \%$ & $9.7 \%$ & $8.3 \%$ \\
\hline
\end{tabular}

*CPI+ is the sum of the annual change in the BLS Consumer Price Index for all Urban Workers (CPI-U) and the BLS Nonfarm Business Sector Output per Hour Worked.

Note: Numbers in parentheses are standard errors. Number of Observations: 113.

Source: Authors' calculations from the Federal Reserve Bank of Cleveland Community Salary Survey, 1956-1996. 
Table 8

\section{Regressions of the Standard Deviation of Employer and Occupation Wage Adjustments on Inflation Expectations and Surprises Separately}

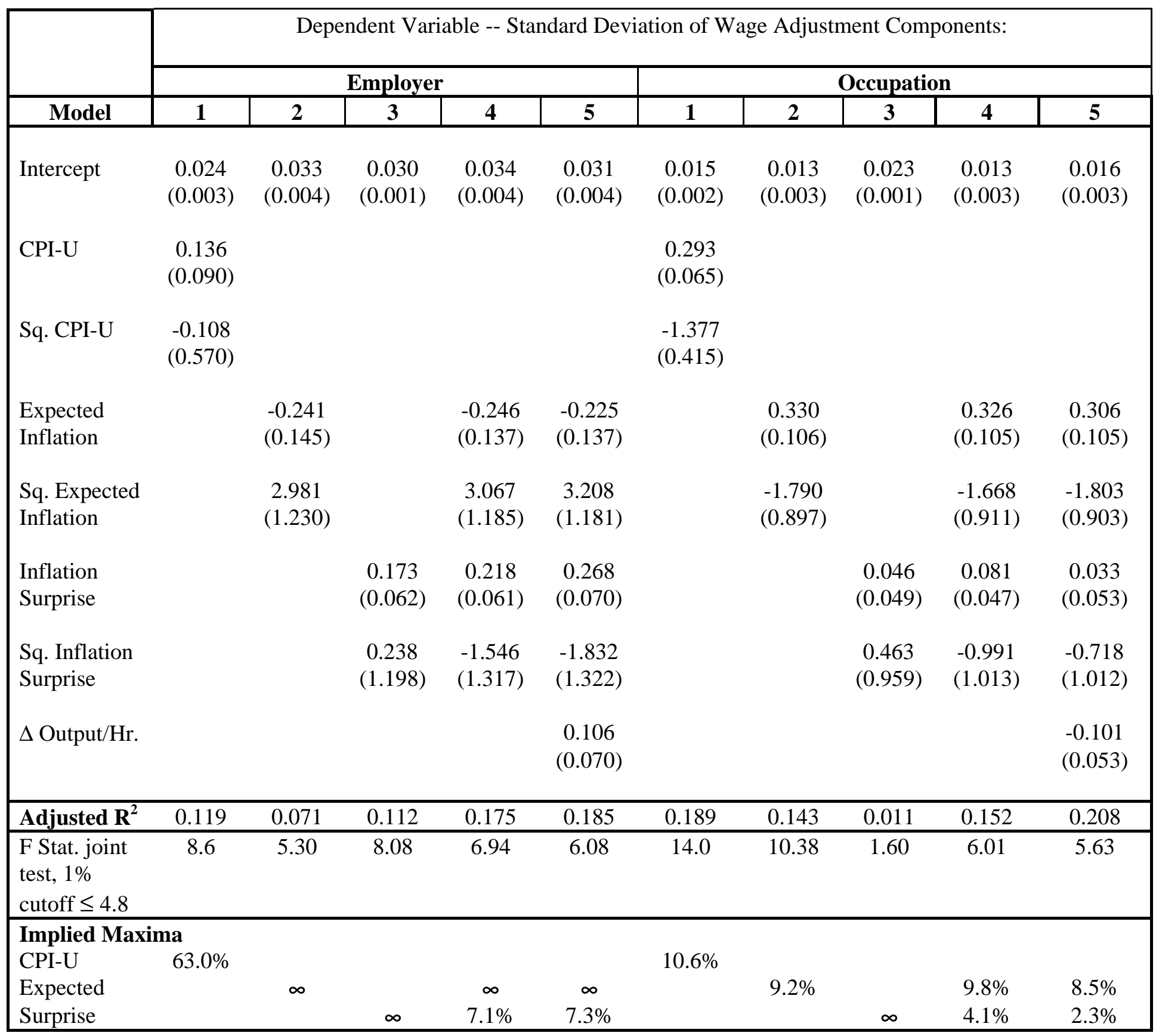

*CPI+ is the sum of the annual change in the BLS Consumer Price Index for all Urban Workers (CPI$\mathrm{U})$ and the BLS Nonfarm Business Sector Output per Hour Worked.

Note: Numbers in parentheses are standard errors. Number of Observations: 113.

Source: Authors' calculations from the Federal Reserve Bank of Cleveland Community Salary Survey, 1956-1996. 
Table 9

Summary of Evidence in Support of Identification Strategy

\begin{tabular}{|c|c|c|}
\hline Probe & Finding & $\begin{array}{l}\text { Consistent with grease and } \\
\text { sand interpretation? }\end{array}$ \\
\hline $\begin{array}{l}\text { 1. Test wage changes } \\
\text { for independent } \\
\text { employer and } \\
\text { occupation } \\
\text { components }\end{array}$ & $\begin{array}{l}\text { Employer and occupational wage } \\
\text { changes are almost fully separable } \\
\text { and distinguishable statistically, } \\
\text { even though data are unbalanced. }\end{array}$ & $\begin{array}{l}\text { Yes. Consistent with two-stage } \\
\text { wage-setting procedure. }\end{array}$ \\
\hline $\begin{array}{l}\text { 2. Plot densities of } \\
\text { low- versus high- } \\
\text { inflation occupational } \\
\text { and employer wage } \\
\text { changes }\end{array}$ & $\begin{array}{l}\text { Occupational adjustments show } \\
\text { evidence of truncation under low } \\
\text { inflation. No such effect for } \\
\text { employer wage changes; lower } \\
\text { inflation simply thins both tails. }\end{array}$ & $\begin{array}{l}\text { Yes. Consistent with downward } \\
\text { rigidity constraining wage cuts } \\
\text { for occupations under low } \\
\text { inflation, and reducing errors or } \\
\text { lags by firms. }\end{array}$ \\
\hline $\begin{array}{l}\text { 3. Compare peak of } \\
\text { occupation and } \\
\text { employer effects }\end{array}$ & $\begin{array}{l}\text { The pace of occupational } \\
\text { adjustments slows at inflation rates } \\
\text { above } 5 \% \text {. Employer wage-change } \\
\text { dispersion shows a higher (perhaps } \\
\text { unbounded) peak. Finding is robust } \\
\text { over all specifications examined. }\end{array}$ & $\begin{array}{l}\text { Yes. Consistent with a grease } \\
\text { effect bounded by the size of real } \\
\text { shocks to skill groups, while } \\
\text { inflation-induced disagreement } \\
\text { among employers has no limit } \\
\text { without indexation. }\end{array}$ \\
\hline $\begin{array}{l}\text { 4. Filter to obtain } \\
\text { low-frequency } \\
\text { occupation changes } \\
\text { and high-frequency } \\
\text { employer adjustments }\end{array}$ & $\begin{array}{l}\text { Little qualitative impact. The shape } \\
\text { of the employer relationship is } \\
\text { driven by short-term changes; the } \\
\text { shape of the occupation relationship } \\
\text { is driven by long-term adjustments. }\end{array}$ & $\begin{array}{l}\text { Yes. Consistent with occupation } \\
\text { adjustments reflecting long-term } \\
\text { market movements and employer } \\
\text { deviations being errors and } \\
\text { corrections. }\end{array}$ \\
\hline $\begin{array}{l}\text { 5. Use panel speci- } \\
\text { fication to control for } \\
\text { lags and employer } \\
\text { and occupation fixed } \\
\text { effects }\end{array}$ & $\begin{array}{l}\text { Little qualitative impact. } \\
\text { Occupation adjustments peak } \\
\text { somewhat earlier, employer effects } \\
\text { peak later, if at all. }\end{array}$ & $\begin{array}{l}\text { Yes. Rules out spurious } \\
\text { autocorrelations and fixed effects } \\
\text { as the source of the estimated } \\
\text { relationships. }\end{array}$ \\
\hline $\begin{array}{l}\text { 6. Divide CPI } \\
\text { between inflation } \\
\text { surprises and } \\
\text { expectations }\end{array}$ & $\begin{array}{l}\text { The pace of occupational } \\
\text { adjustments rises only with inflation } \\
\text { expectations -- not with surprises. } \\
\text { Inflation surprises matter more than } \\
\text { expectations for raising employer } \\
\text { disagreement. }\end{array}$ & $\begin{array}{l}\text { Yes. Consistent with expected } \\
\text { inflation providing leeway for } \\
\text { intended occupational } \\
\text { adjustments, while price-level } \\
\text { surprises cause more unintended } \\
\text { adjustments among employers. }\end{array}$ \\
\hline $\begin{array}{l}\text { 7. Control for } \\
\text { cyclical } \\
\text { unemployment and } \\
\text { secular time trend }\end{array}$ & $\begin{array}{l}\text { Little qualitative impact. But, } \\
\text { independent of inflation, } \\
\text { occupational adjustments rise } \\
\text { strongly with unemployment, while } \\
\text { employer adjustments are } \\
\text { unaffected. }\end{array}$ & $\begin{array}{l}\text { Yes. Rules out interpretations of } \\
\text { the results as the product of time, } \\
\text { business cycles or trends } \\
\text { correlated with the level of } \\
\text { inflation, such as worker-quality } \\
\text { fluctuations. }\end{array}$ \\
\hline
\end{tabular}


Figure 1: CSS Mean Wage Change Versus CPI+, 1957-1996

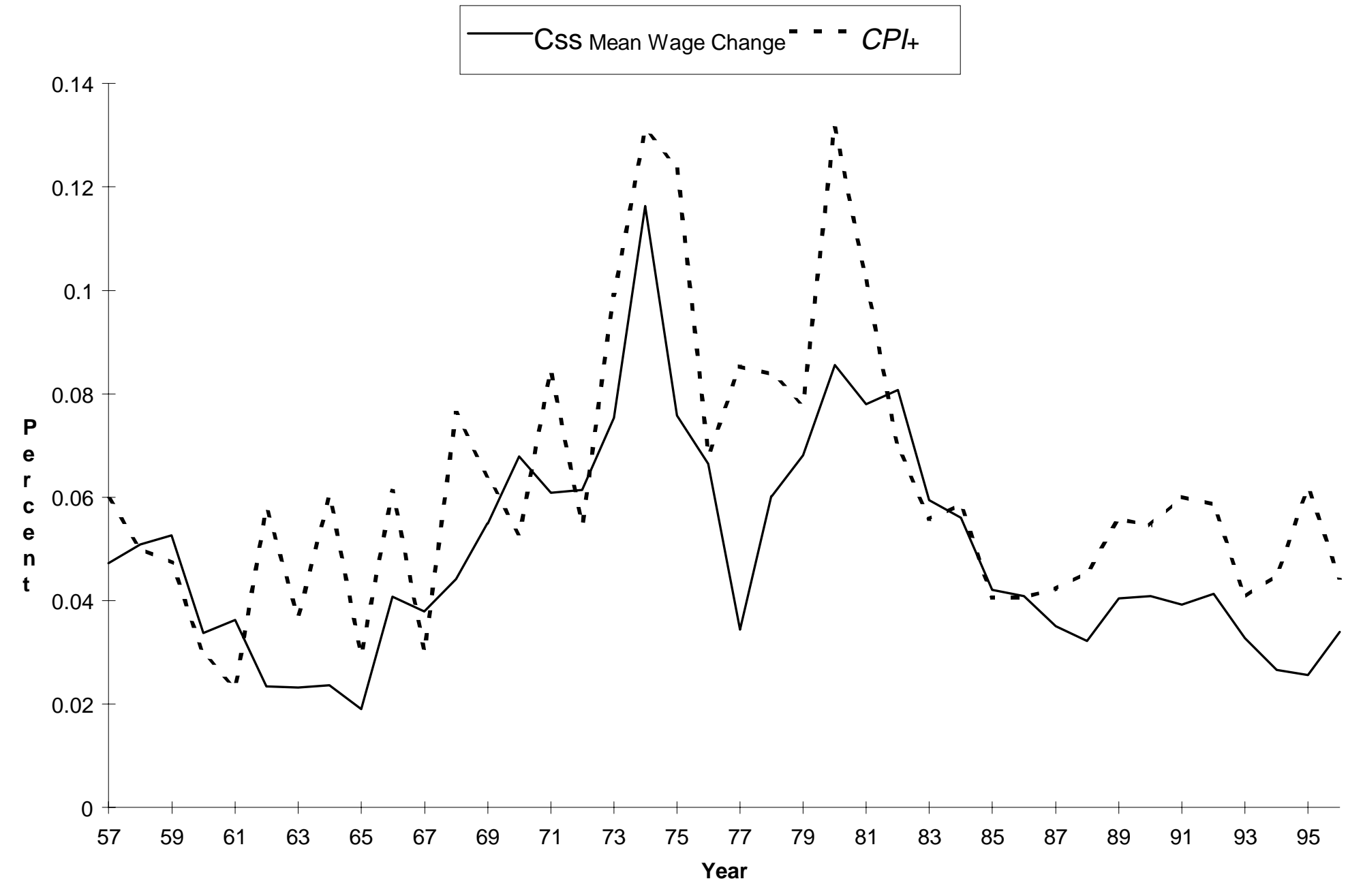


Figure 2A: Density of CSS Employer Adjustments During High and Low Inflation Years

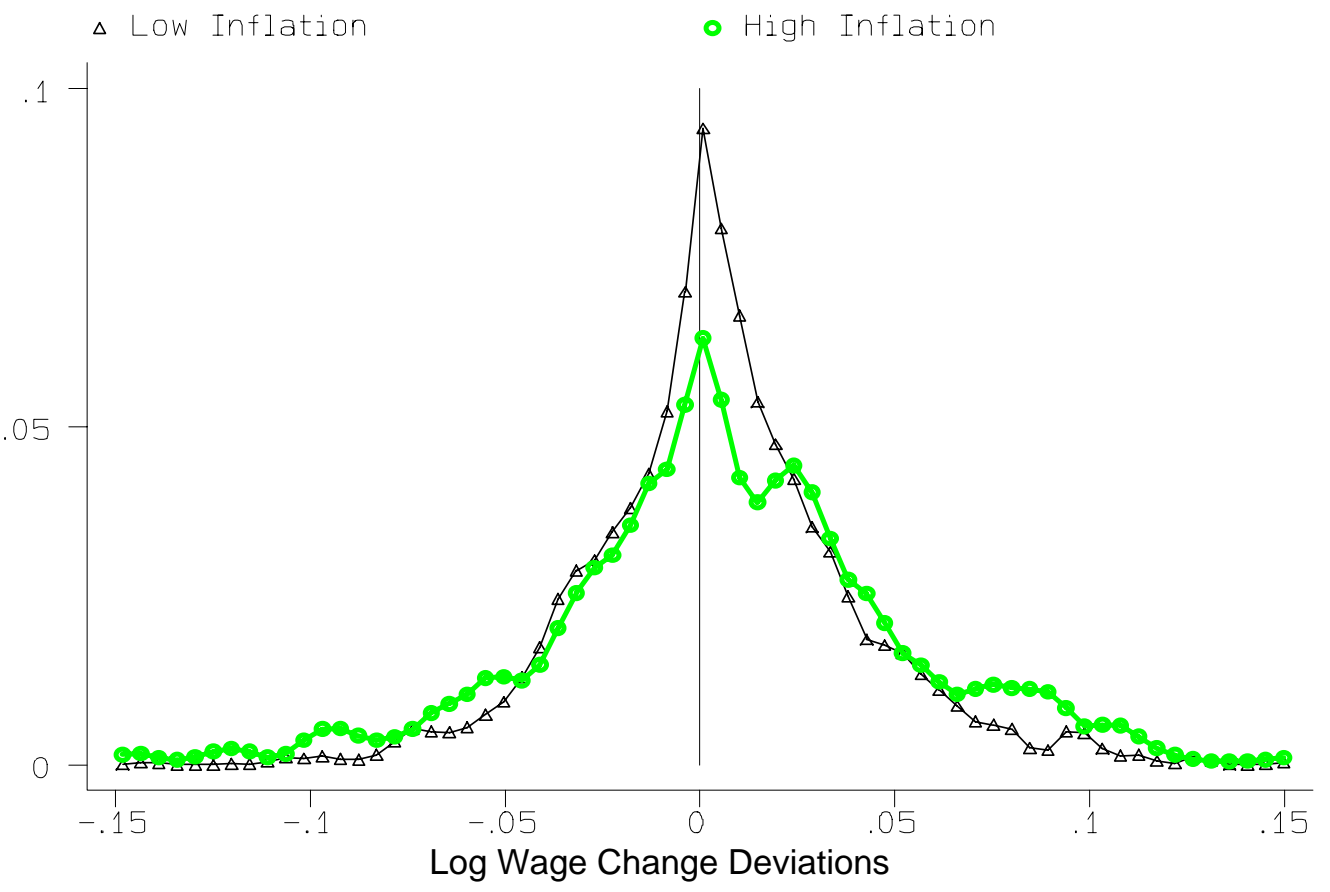

Figure 2B: Density of CSS Occupational Adjustments During High and Low Inflation Years

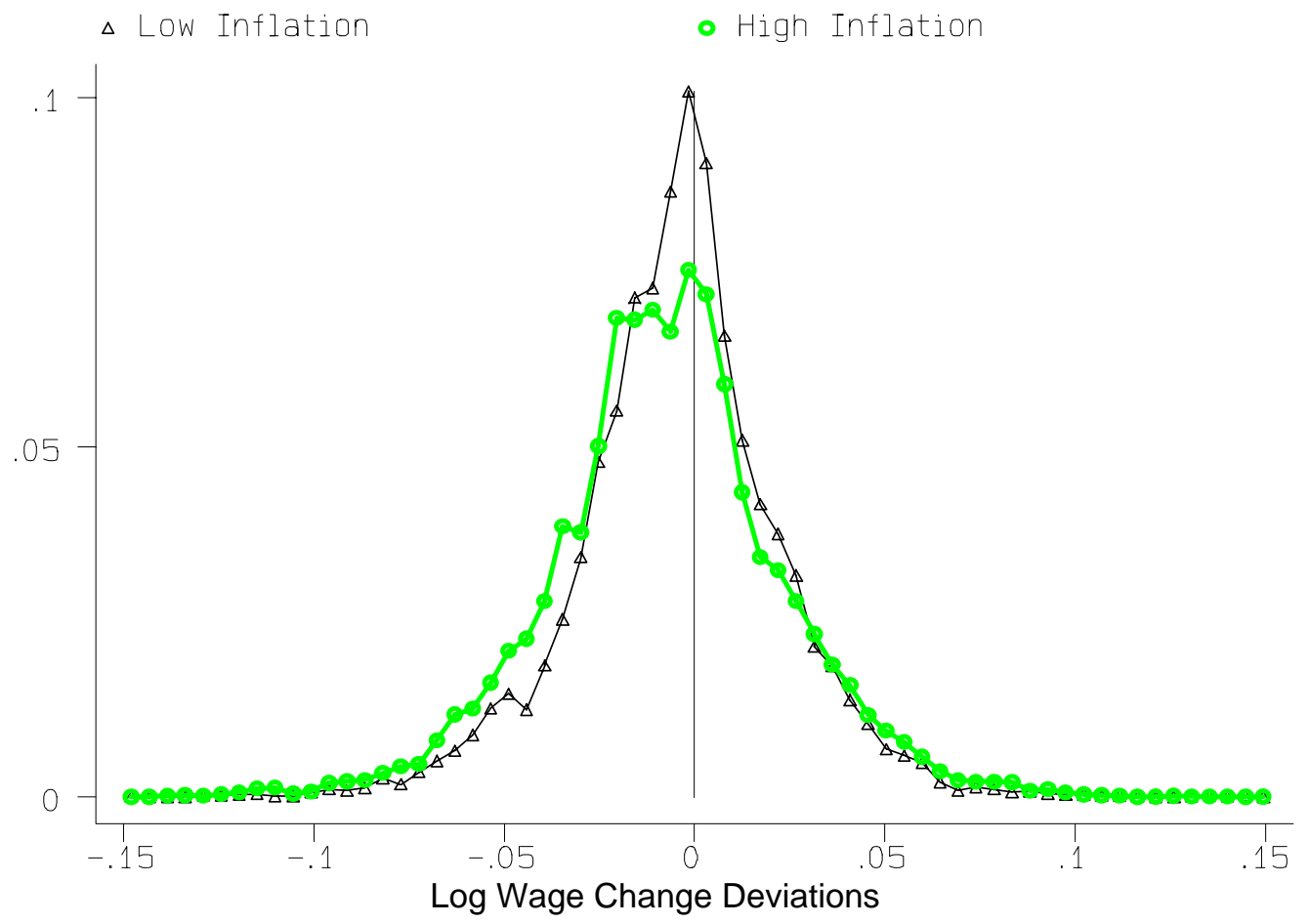


Figure 3A: Standard Deviations of CSS Employer Adjustments Associated with $\mathrm{CPI}+$ on Extended Sample: Nonparametric and Regression Predictions

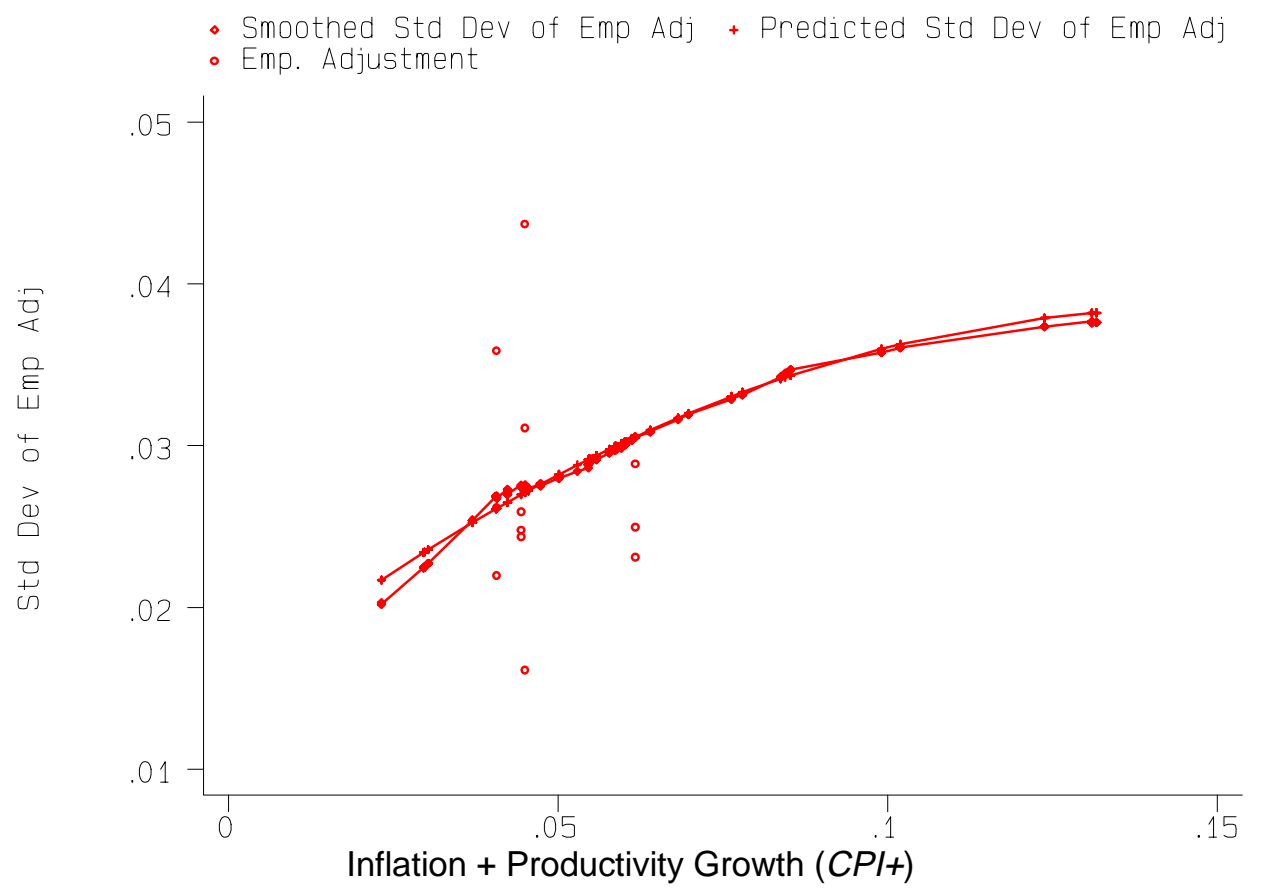

Figure 3B: Standard Deviations of CSS Occupational Adjustments Associated with $\mathrm{CPI}+$ on Extended Sample: Nonparametric and Regression Predictions

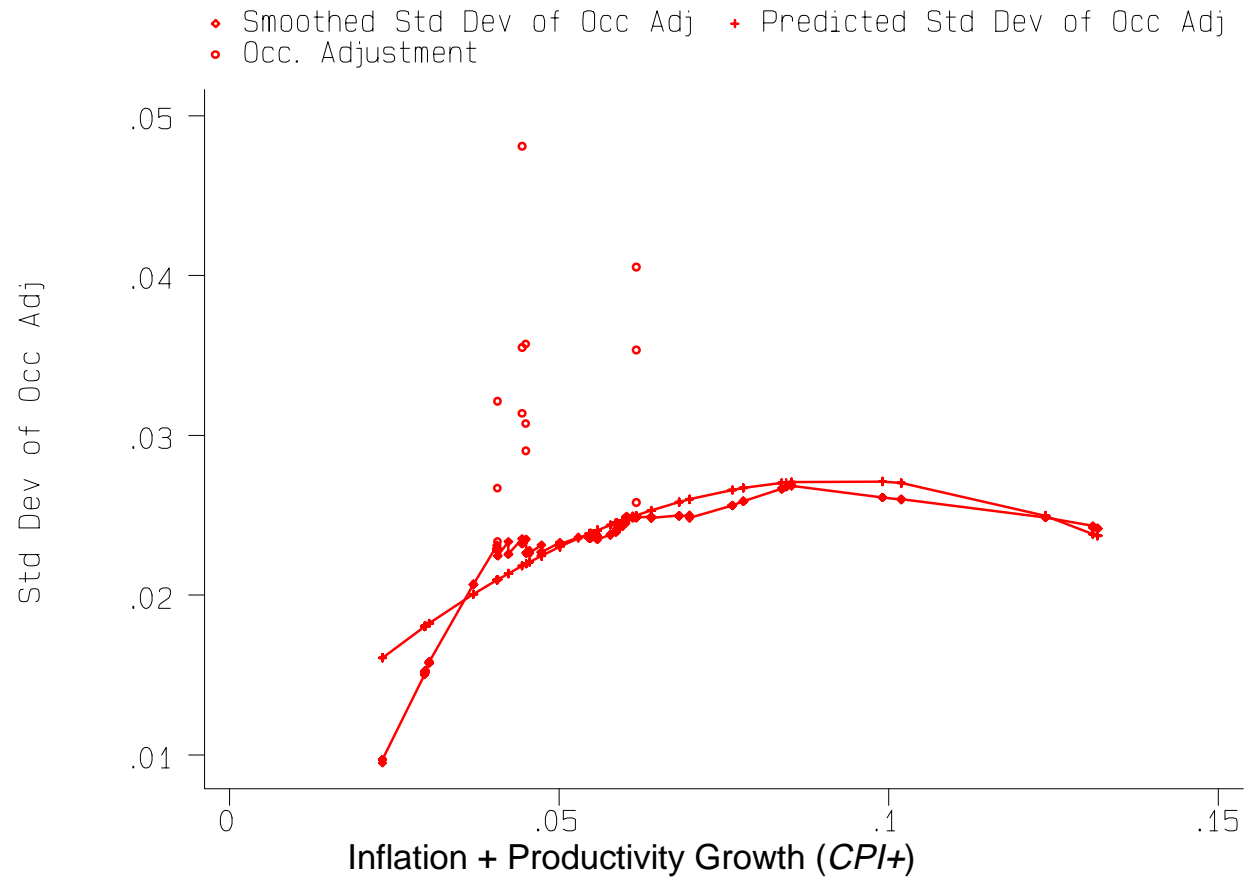

Note: In each case, the smooth line is the fitted quadratic relationship, while the kinked line is the nonparametric version of the same relationship. 
Figure 4: Aggregate Relationship Between US Unemployment Rate and CPI+ (CPI-U Plus Change in Output/Hour), 1956 - 1996

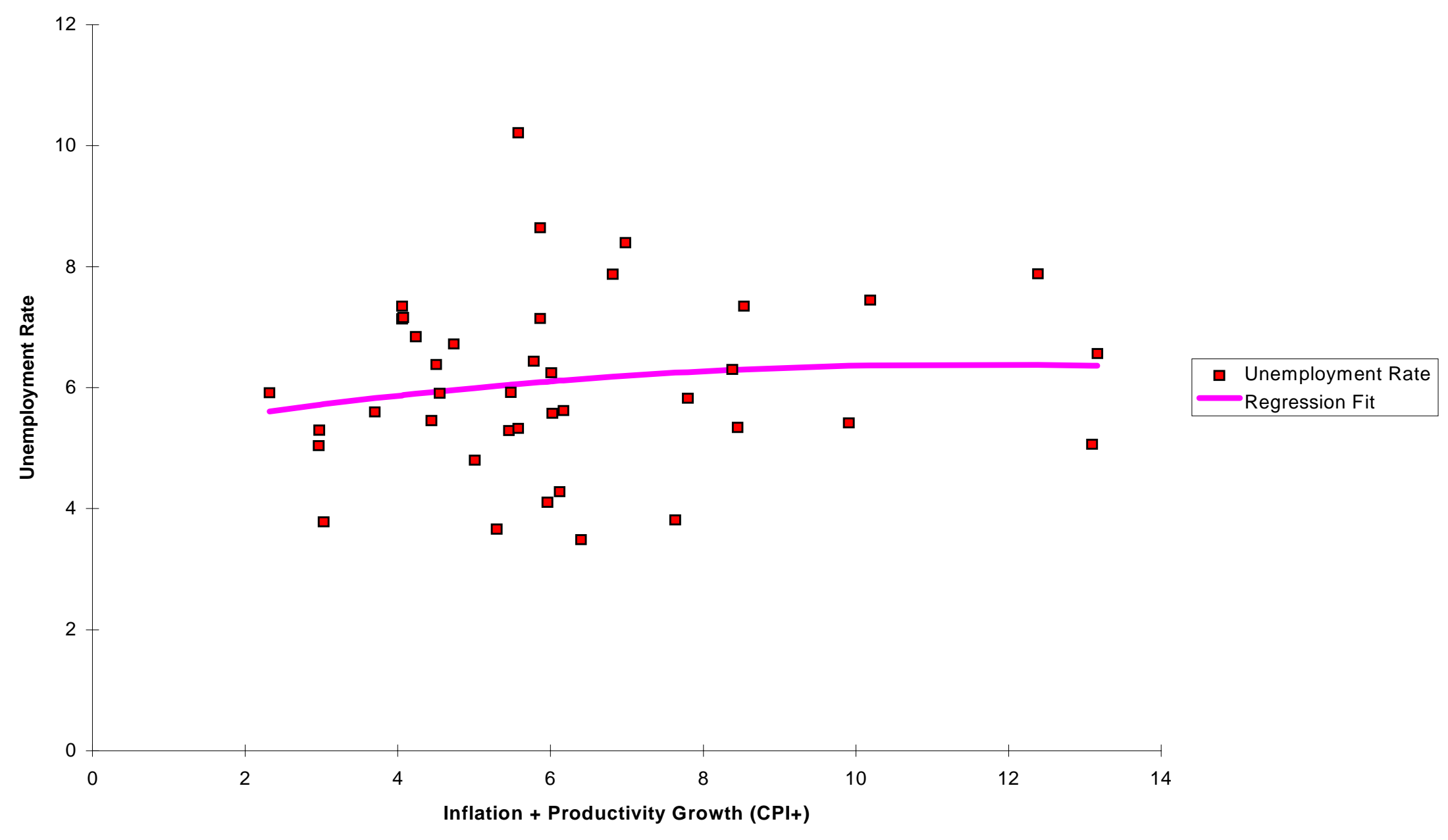


Figure 5: Estimated Net Effects of Inflation, Using Extended CSS Sample (Assuming Productivity Growth of 1.5\%)

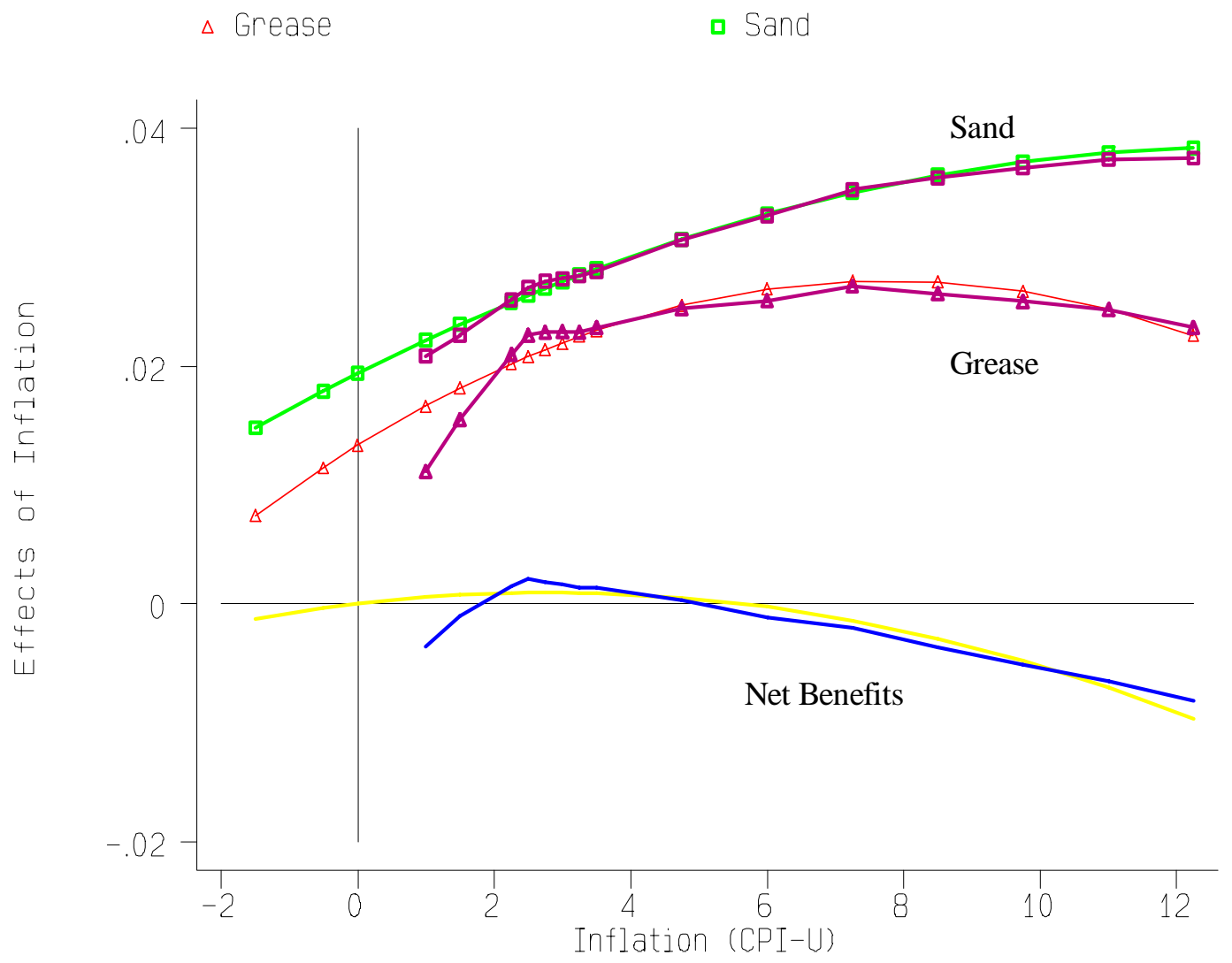

Note: In each case, the smooth line is the fitted quadratic relationship, while the kinked line is the nonparametric version of the same relationship. The horizontal axis measures effects of inflation on the standard deviation of log wage changes. The grease effect is assumed to be beneficial because the adjustments are intended responses to changing labor market conditions among occupations. The sand effect is disruptive because it reflects unintended deviations from parity with other employers -- due to errors or lags. Net benefits also assume that gross benefits and costs of inflation are zero when the inflation rate is zero. 
Figure 6: Simulated Net Effects of $\mathrm{CPI}$ (CPI-U Plus Change in Output/Hour) on Unemployment, Based on CSS Results

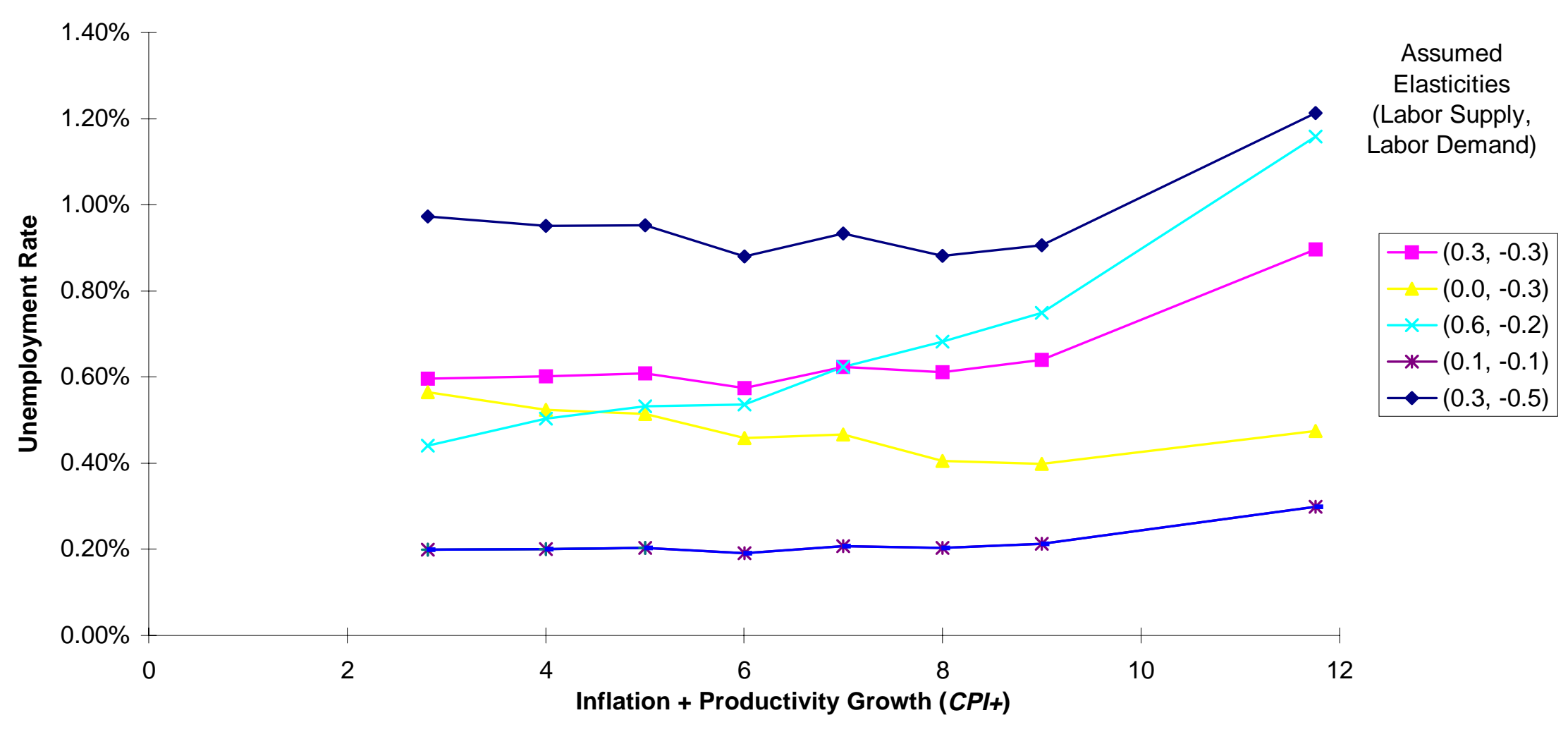




\section{References}

Abraham, Katharine G. and John C. Haltiwanger. "Real Wages and the Business Cycle," Journal of Economic Literature, vol. 33, no. 3 (September 1995), pp. 1215-64.

Akerlof, George A., William T. Dickens and George L. Perry. "The Macroeconomics of Low Inflation.” Brookings Papers on Economic Activity Q1 1996, pp. 1-74.

Andres, Javier and Ignacio Hernando. "Does Inflation Harm Economic Growth? Evidence for the OECD." NBER Conference on "The Costs and Benefits of Achieving Price Stability. 1997.

Ball, Laurence and Stephen G. Cecchetti. "Inflation and Uncertainty at Short and Long Horizons.” Brookings Papers on Economic Activity, Q1, 1990, pp. 215-54.

Bewley, Truman and William Brainard. "A Depressed Labor Market, as Explained by Participants," Cowles Foundation, Yale University, mimeo (February 1993).

Blinder, Alan S. and Don H. Choi. "A Shred of Evidence on Theories of Wage Stickiness," Quarterly Journal of Economics, vol. 105 , no. 4 (November 1990), pp. 1003-1015.

Bryan, Michael F. and William T. Gavin. "Models of Inflation Expectations Formation," Journal of Money, Credit, and Banking, vol. 18, no. 4 (November 1986), pp. 539-44.

Card, David and Dean Hyslop. "Does Inflation "Grease" the Wheels of the Labor Market?” Industrial Relations Section Working Paper :??? Princeton University 1996.

Cleveland, William S. "Robust Locally Weighted Regression and Smoothing Scatter Plots," Journal of the American Statistical Association, vol. 79 (1979), pp. 829836.

Drazen, Allan and Daniel S. Hamermesh. "Inflation and Wage Dispersion," National Bureau of Economic Research Working Paper no. 1811, January 1986.

Fortin, Pierre. "The Great Canadian Slump," Canadian Journal of Economics, forthcoming.

Freedman, Audrey. The New Look in Wage Policy and Employee Relations, The Conference Board, Report No. 865, 1976.

Friedman, Milton. "Nobel Lecture: Inflation and Unemployment." Journal of Political Economy, vol. 85, no. 3, 1977, pp. 451-72. 
Groshen, Erica L. “Do Wage Differences among Employers Last?” Federal Reserve Bank of Cleveland, Working Paper 8906, June 1989 (revised 1991).

Groshen, Erica L. "American Employer Salary Surveys and Labor Economics Research: Issues and Contributions," Annales d'Economie et de Statistique, no. 41/42 (1996), pp. 414-42.

Groshen, Erica L. and Mark E. Schweitzer. "The Effects of Inflation on Wage Adjustments in Firm-Level Data: Grease or Sand?" Federal Reserve Bank of New York Staff Report No. 9, January 1996 (Latest version: December 1996).

Groshen, Erica L. and David I. Levine. "The Rise and Decline(?) of Internal Labor Markets" mimeo, April 1997.

Haley, James. "Theoretical Foundations for Sticky Wages," Journal of Economic Surveys, vol. 4, no. 2 (1990), pp. 115-155.

Hamermesh, Daniel S. Labor Demand. Princeton, NJ: Princeton University Press, 1993.

Hills, F.S. Compensation Decision Making. Hinsdale, IL: Dryden Press, 1987.

Kahn, Shulamit. "Evidence of Nominal Wage Stickiness from Microdata." Unpublished paper. Boston University School of Management (1995).

Killingsworth, Mark R. and James J. Heckman. "Female Labor Supply: A Survey," In O. Ashenfelter and R. Layard, eds., Handbook of Labor Economics. Amsterdam: North-Holland, Elsevier Publishers, 1986, pp. 103-204.

Lach, Saul, and Daniel Tsiddon. "The Behavior of Prices and Inflation: An Empirical Analysis of Disaggregated Price Data," Journal of Political Economy, vol. 100, no. 2 (1992), pp. 349-389.

Lebow, David E., David J. Stockton, and William L. Wascher. "Inflation, Nominal Wage Rigidity, and the Efficiency of Markets," Division of Research and Statistics, Board of Governors of the Federal Reserve System, mimeo, August 1993.

Levine, David I. "Fairness, Markets, and Ability to Pay: Evidence from Compensation Executives," American Economic Review, vol. 83, no. 5 (December 1993), pp. 1241-1259.

McLaughlin, Kenneth J. "Rigid Wages?” Journal of Monetary Economics, vol. 34, no. 3 (1994), pp. 383-414. 
Milkovich George and J.M. Newman. Compensation. Homewood, IL: BPIIrwin, 1990.

Pencavel, John. "Labor Supply of Men: A Survey," In O. Ashenfelter and R. Layard, eds., Handbook of Labor Economics. Amsterdam: North-Holland, Elsevier Publishers, 1986, pp. 3-102.

Reder, Melvin. “The Theory of Occupational Wage Differentials.” American Economic Review, vol. 45, no. 5 (December 1955), pp. 833-852.

Sheshinski, Eytan and Yoram Weiss. "Inflation and Costs of Price Adjustment," Review of Economic Studies, vol. 44, no. 2 (June 1977), pp. 287-303.

Tobin, James. "Inflation and Unemployment." American Economic Review, vol. 62, no. 1 (March 1972), pp. 1-18.

Vining, Daniel R. and Thomas C. Elwertowski. "The Relationship between Relative Prices and the General Price Level," American Economic Review, vol. 66, no. 4 (September 1976), pp. 699-708.

Wallace, M.J. and C.H. Fay. Compensation Theory and Practice. Boston:PWSKent. 1988. 


\section{Appendix Description of Unemployment Simulation Exercise}

This section describes the process used to arrive at the unemployment simulations results reported in the text and figure 6. We generate artificial data consistent with various key features of the CSS.

The simulated data are constructed to mimic the CSS in three ways: 1) an identical firm, occupation, city structure to that shown in tables 1 and 2, so that any limitations on the identification strategy due to the number of cells with given characteristics is replicated; 2) the same levels of overall variation by year, city, occupation, firm, and residual, as seen in table 4; and, 3) regression coefficients approximately matching the basic (stage two) estimates shown in table 5. From these results we calculate unemployment impacts for grease and sand, using labor supply and demand elasticities estimated elsewhere.

Underlying wage-changes are assigned a trend equal to inflation plus productivity growth. Around that trend, we allow the following five sources of variation: occupation, firm (uncorrelated with inflation and general productivity growth), firm uncertainty, city, and residual (which accounts for all other sources of wage change variation). If the total wage-change sums to less than zero, it is truncated with a fixed probability.

The parameterization we use parallels results in Stages 1 and 2 of the CSS statistical model. In any year, both firm and occupation effects are allowed to vary 12 percent as much as total wage changes. Firm variation also rises with inflation and productivity $(C P I+)$. The slope of the relationship -- 0.18 -- was chosen so that the sand component accounts for half of total firm variation. Variation in the raw (pre-truncated) residual is set slightly greater than the total CSS variation -- so that ANOVA results for post-truncation simulated data resemble those observed in Stage 1. Independent city variation is set to zero, because the firm variation already generates comparable city effects. Firms truncate the wages of workers with negative total (raw) wage changes 75 percent of the time. This frequency of truncation replicates Stage 2 grease estimates. 